\title{
GC-MS ANALYSIS OF BIOACTIVE COMPOUNDS IN ETHANOL LEAVES EXTRACT OF SPHENOCENTRUM JOLLYANUM AND THEIR BIOLOGICAL ACTIVITIES.
}

\author{
Emmanuel Uka1, Queensley A. Eghianrunwa ${ }^{2}$, Violet D.Akwo ${ }^{3}$ \\ ${ }^{1}$ Emmanuel Uka Department of Biochemistry, Faculty of Science, University of Uyo \\ ${ }^{2}$ Queensley A. Eghianrunwa Department of Biochemistry, Faculty of Science, University of Uyo \\ 3 Violet D.Akwo Department of Biochemistry, Faculty of Science, University of Uyo
}

\begin{abstract}
Sphenocentrum jollyanum is a plant genus of the family Menispermaceae. It has high medicinal importance as it is used traditionally to treat various diseases such as jaundice, breast engorgement related to the menstrual cycle, tumour, fibroids and improve the health of people. The present investigation was carried out to analyze the bioactive compounds present in ethanol crude extract of Sphenocentrum jollyanum leaves using GC-MS analysis. GC-MS analysis of ethanol extract Sphenocentrum jollyanum was done using a 7890A GC system (Agilent Technologies), coupled with 5977B MSD (Agilent Technologies) while the mass spectra of the compounds found in the extract was matched with the National Institute of Standards and Technology (NIST) library. A total of 45 bioactive compounds representing $99.98 \%$ of the total extract based on the retention time, peak area, molecular formula, molecular weight, and biological activities were identified by GC-MS which ranges from high molecular weight to low molecular weight compounds. The major compounds identified with their peak area percentages were 2,4-Di-tertbutylphenol, (21.05\%), Z-8-Methyl-9-tetradecenoic acid (19.12), Hexadecanoic acid, ethyl ester (7.86\%), Diisooctyl phthalate (7.13\%), Phytol, Oleic Acid (7.03), 6,9,12Octadecatrien-1-ol (6.65\%), 3-Eicosene, (E)-(4.63\%), 2-Methyl-Z, Z-3,13-octadecadienol (4.24\%), nHexadecanoic acid (4.09\%), trans-13-Octadecenoic acid (3.81\%), Cyclohexene, 4-(4-ethylcyclohexyl) -1pentyl- (3.74\%), Dibutyl phthalate (3.20\%), and 9-Oxabicyclo (6.1.0) nonane, cis-(3.18\%). The presence of these major phytoconstituents in the leaf extract provides various biological activities including antifungal, antibacterial, antioxidant, anti-inflammatory, and anti-tumour which supports the ethno-medicinal uses of the plant in curing diseases. We recommend further studies be carried out on the isolation, biosynthesis and characterization of the compounds.
\end{abstract}

Key words: GC-MS analysis, Bioactive compounds, Sphenocentrum jollyanum, Ethanol leaf extract, biological activity.

\section{INTRODUCTION}

Mankind since ancient times has depended upon the plant kingdom to meet all their medicinal needs. This prompted early men to explore their immediate natural surrounding and try many plants, animal products, mineral and develop a variety of therapeutic agents (Biren and Seth, 2017).

It is now advocated by the World Health Organization that universal health coverage and the integration of safe and effective traditional providers and complementary services into self-care practices and health service delivery, be focused on herbal medicine (Ipsos, 2008). Kalyany 2019 reported that over 4 billion people of the 
world population presently use herbal medicine for primary health care. These medicinal plants are the most important source of organic compounds and one of such plants is Sphenocentrum jollyanum.

Sphenocentrum jollyanum, a perennial plant native to the tropical forest zone of West Africa, belongs to the family Menispermaceae. (Nia et al., 2004). It is widely distributed in Sierra Leone, Nigeria, Ghana, Ivory Coast, and Cameroun (Nia, 2004). Sphenocentrum jollyanum is a small erect sparsely branched shrub which grows up to $1.5 \mathrm{~m}$ in height. It is locally known as "Aduro kokoo" (red medicine), "Okramankote" (dog's penis), Oban abe, and Ouse-abe among the people of Ghana, Republic of Benin, and Côte d'Ivoire respectively (Amidu, 2008). It is known locally in Nigeria as Oji-enyi, Ajo or Akerejupon and Ibong Isong among the Igbos, Yorubas and the Ibibios respectively (Nia et al., 2004).

Sphenocentrum jollyanum is an important medicinal plant that contains high level phytochemicals. These include flavonoids, saponins, terpenoids, isoquinoline alkaloids such as palmatine, columbamine and some other alkaloids. The most abundant of the phytochemicals are the alkaloids (Woode et al., 2009). Most of the biologic/ therapeutic effects of the plant are attributed to the chemical constituent. Many scientific research has reported the effects of the plant in respects to its sexual stimulant roles (Owiredu et al., 2007), hepatoprotective effects (Olorunnisola et al., 2011), wound healing property, antiviral and anti-inflammatory activities (Moody et al., 2006), antidiabetic (Mbaka et al., 2011), antioxidant and analgesic properties (Nia et al., 2004), treating jaundice, breast engorgement related to the menstrual cycle, and tumour (Iwu, 1993). The charred fruit is used in treatment of fibroids in traditional Nigerian medicine (Egunyomi et al., 2005) while the root hair is used with other anti-malaria plant as remedies against fevers, body pains and rheumatism (Burkill, 1985).

Gas chromatography-mass spectroscopy (GC-MS) is a combined analytical technique used to determine and identify compounds present in a plant sample (Uma and Balasubramaniam, 2012). It plays an essential role in the phytochemical analysis and chemotaxonomic studies of medicinal plants containing biologically active components (Héthelyi et al., 1987). Applications of GC-MS include drug detection, fire investigation, environmental analysis, explosives investigation, and identification of unknown samples. However, fewer reports are available for the pharmacological properties of Sphenocentrum jollyanum. Keeping this in view, the present study has been undertaken to determine the bioactive compounds in crude ethanol leaf extract of Sphenocentrum jollyanum. 


\section{MATERIALS AND METHODS}

\subsection{Chemicals and reagents}

All the chemicals and reagents used for the research were of analytical grade

\subsection{Collection, Identification and Authentication of Plant materials}

Fresh leaves of Sphenocentrum jollyanum were harvested from Aka in Ibiono Ibom Local Government Area of Akwa Ibom State, Nigeria.

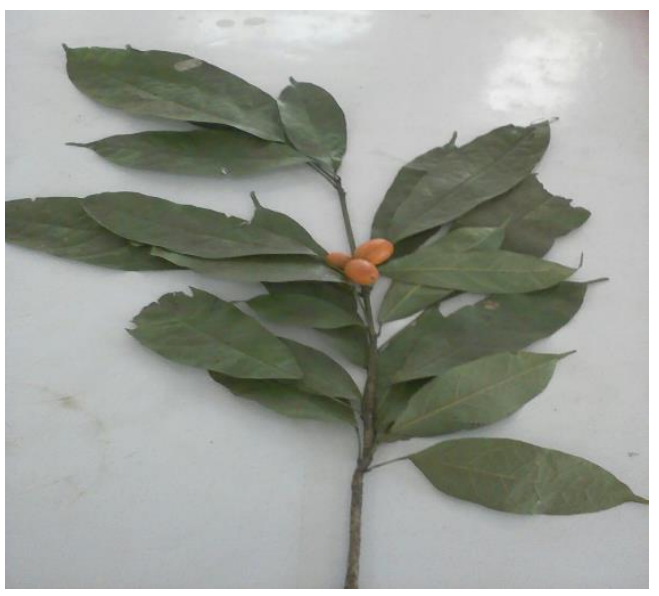

Fig: 1. Leaves of Sphenocentrum jollyanum

The Leaves were identified and authenticated by Mr. Etefia of the Department of Pharmacognosy and Natural Medicine, University of Uyo, Nigeria. The plant was deposited at the herbarium of Department of Pharmacognosy and Natural Medicine, University of Uyo, Nigeria with the voucher No: NUUH: 040 (Uka et al., 2021a).

\subsection{Preparation of Extract}

Fresh leaves of Sphenocentrum jollyanum were thoroughly washed under running tap water to remove dust particles, air-dried for two weeks at ambient room temperature to obtain a fixed weight. The dried leaves were pulverized into a coarse powder using VTCL Solitaire mixer grinder (VTCL, India). Powdered leaf sample (400 g) was extracted in $60 \%$ ethanol for 72 hours with intermittent stirring and filtered using Whatman No 1 filter paper. The filtrate obtained was concentrated in a water bath at $40{ }^{\circ} \mathrm{C}$ to completely remove the solvent (Uka $e t$ al., 2021b). The crude extract was subjected to GC-MS analysis. 


\subsection{GC-MS analysis of ethanol extract of Sphenocentrum jollyanum leaves}

GC-MS technique was used in this study to identify the various compounds present in the ethanol leaf extract of Sphenocentrum jollyanum. Gas Chromatography-Mass Spectroscopy (GC-MS) analysis was carried out at the Multi-User Science Research Laboratory, Ahmadu Bello University (ABU), Zaria, Nigeria. GC-MS analysis of this extract was performed using a 7890A GC system (Agilent Technologies), coupled with a Mass Selective Detector (MSD) 5977B (Agilent Technologies) driven by Agilent Chem-Station software package. The GC was equipped with an Agilent HP-5MS non-polar capillary column of $30 \mathrm{M}$ length, $0.25 \mathrm{~mm}$ internal diameter and $0.25 \mu \mathrm{m}$ film thickness as the stationary phase. The analysis was carried out using helium gas as the carrier gas as well as an eluent with a flow rate of $1.0 \mathrm{~mL} /$ minute in split less mode. About $1.0 \mu \mathrm{L}$ of the ethanol extract of Sphenocentrum jollyanum (dissolved in methanol) was injected into the GC-MS using a micro syringe with the oven temperature programmed at $40{ }^{\circ} \mathrm{C}$ and then raised to $250{ }^{\circ} \mathrm{C}$ at the rate of $5{ }^{\circ} \mathrm{C} / \mathrm{min}$ with a hold time of 3 min. The injector was held at $300{ }^{\circ} \mathrm{C}$ and the mass spectra were obtained by electron ionization voltage (EI) at $70 \mathrm{eV}$ with a scan range of 40 to 650 mass-to-charge $(\mathrm{m} / \mathrm{z})$ ratio. The constituent compounds of the Sphenocentrum jollyanum were identified by direct comparison with that of the NIST database based on their retention time (RT), Molecular formula (MF), Molecular weight (MW), and mass spectral data with already known compounds in the National Institute of Standards and Technology 14 library (2018) database. This study was carried out to determine the classes of chemical compounds present in Sphenocentrum jollyanum expressed as a percentage based on peak area produced in the chromatogram.

\subsection{Identification of compounds}

GC-MS Chromatogram of Sphenocentrum jollyanum revealed fifteen peaks showing that forty-five different phytochemicals were present. Identification of phytochemical compounds and interpretation of mass spectrum of GC-MS was conducted using the database of National Institute Standard and Technique 2014 (NIST-2014) having more than 243,000 patterns. The retention indices, peak area percentage and spectrum of the unknown components was compared with the spectrum of the known components of the NIST library and also with published literature. The name, molecular weight, molecular formula, structure and bioactivities of the phytochemicals of the components of the test materials were ascertained by the mass hunter software. 


\section{RESULTS}

GCMS is one of the most precise techniques to separate and identify various secondary metabolites present in plant extract such as fatty acid esters, phenylpropane, aliphatic, fatty alcohol, aliphatic alcohol etc. The ethanol leaf extract of Sphenocentrum jollyanum was analyzed by GCMS to detect various compounds with the help of NIST database. The results of the GC-MS chromatogram showed 15 peaks with 45 chemical compounds corresponding to $99.98 \%$ of the entire extract (Table 1). The different bioactive compounds with the retention time and peak range between 5.255 to 22.685 and 21.05 to $1.47 \%$ respectively. The identified compounds were based on their peak, retention time, peak area (\%), compound name, chemical structure, molecular formula, molecular weight and bioactivity confirmed by comparing the mass spectra obtained with literature mass spectra where available. The detailed phytocomponents and their biological activities obtained from GC-MS analysis of Sphenocentrum jollyanum are summarized in Tables 2, 3. Figures 2,3,4,5,6,7,8,9,10,11 and 12 showed the GCMS chromatogram and the spectra of different components of Sphenocentrum jollyanum.

The results revealed the presence of 2,4-Di-tert-butylphenol, Phenol, 3,5-bis(1,1-dimethylethyl) (21.05\%), Cyclohexene, 6-butyl-1-nitro, Z-8-Methyl-9-tetradecenoic acid, Methyl 9,12-heptadecadienoate (19.12\%), Hexadecanoic acid, ethyl ester, Undecanoic acid, ethyl ester (7.86\%), Diisooctyl phthalate, Bis(2-ethylhexyl) phthalate, (7.13\%), Phytol, Oleic Acid, cis-11-Hexadecenal (7.03\%), 6,9,12-Octadecatrien-1-ol, Ethanol, 2(9,12-octadecadienyloxy)-, (Z, Z)- (6.65\%), 5-Eicosene, (E)-, 3-Eicosene, (E)-. 1-Octadecene (4.63\%), 9,17Octadecadienal, (Z)-, 2-Methyl-Z, Z-3,13-octadecadienol, cis-7, cis-11 Hexadecadien-1-yl acetate (4.24\%), nHexadecanoic acid, n-Decanoic acid, L-Galactose, 6-deoxy-, (4.09\%), trans-13-Octadecenoic acid, 1-Eicosene (3.81\%), Cyclohexene, 4-(4-ethylcyclohexyl) -1-pentyl-,9-Octadecenoic acid (Z)-,2,3-dihydroxypropyl ester, 9-Oxabicyclo [6.1.0] nonane (3.74\%), Dibutyl phthalate, 1,2-Benzenedicarboxylic acid, butyl 2 methyl propyl ester, 1,2-Benzenedicarboxylic acid, butyl 2-ethylhexyl ester (3.20\%), 9-Oxabicyclo [6.1.0] nonane, cis-, 2Methyl-Z, Z-3,13-octadecadienol, 8-Dodecen-1-ol, (Z)-(3.18\%), Cetene,1-Hexadecanol, Trifluoroacetic acid, n-tridecyl ester, (2.78\%), 9-Octadecenoic acid (Z)-,2-hydroxy-1-(hydroxymethyl) ethyl ester, 9,12Octadecadien-1-ol, (Z, Z)-,(1.47\%). These phytochemicals are responsible for various biological activities like antifungal, antibacterial, antidepressant, antioxidant, anti-inflammatory, and anti-tumour activities of the leaf extract which supports traditional and modern use of Sphenocentrum jollyanum in curing various diseases. 
Abundance

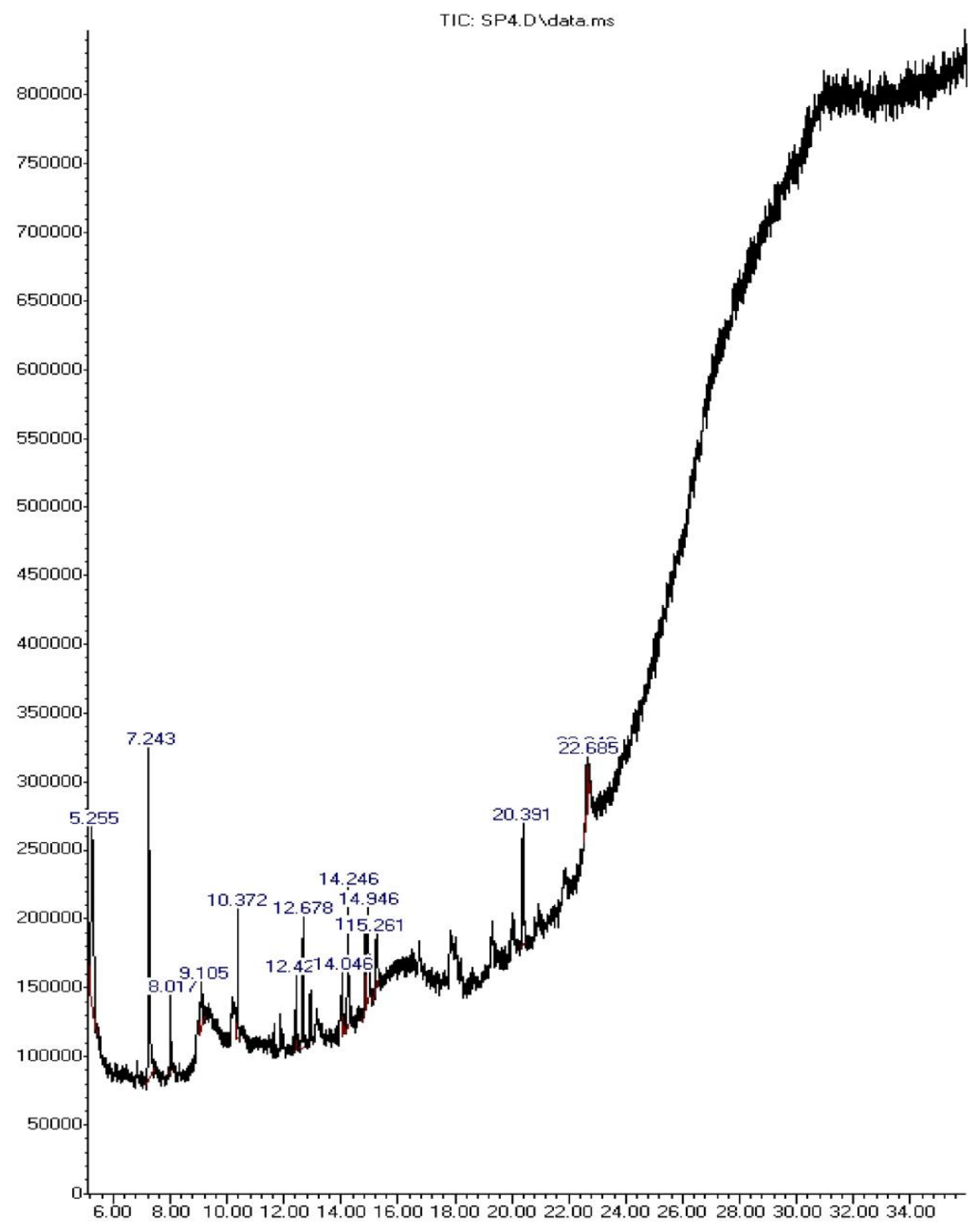

Time-->

Figure 2. Typical GC-MS chromatogram of ethanol extract of Sphenocentrum jollyanum 
Table 1: Identified phytochemical compounds in crude ethanol leaf extract of Sphenocentrum jollyanum

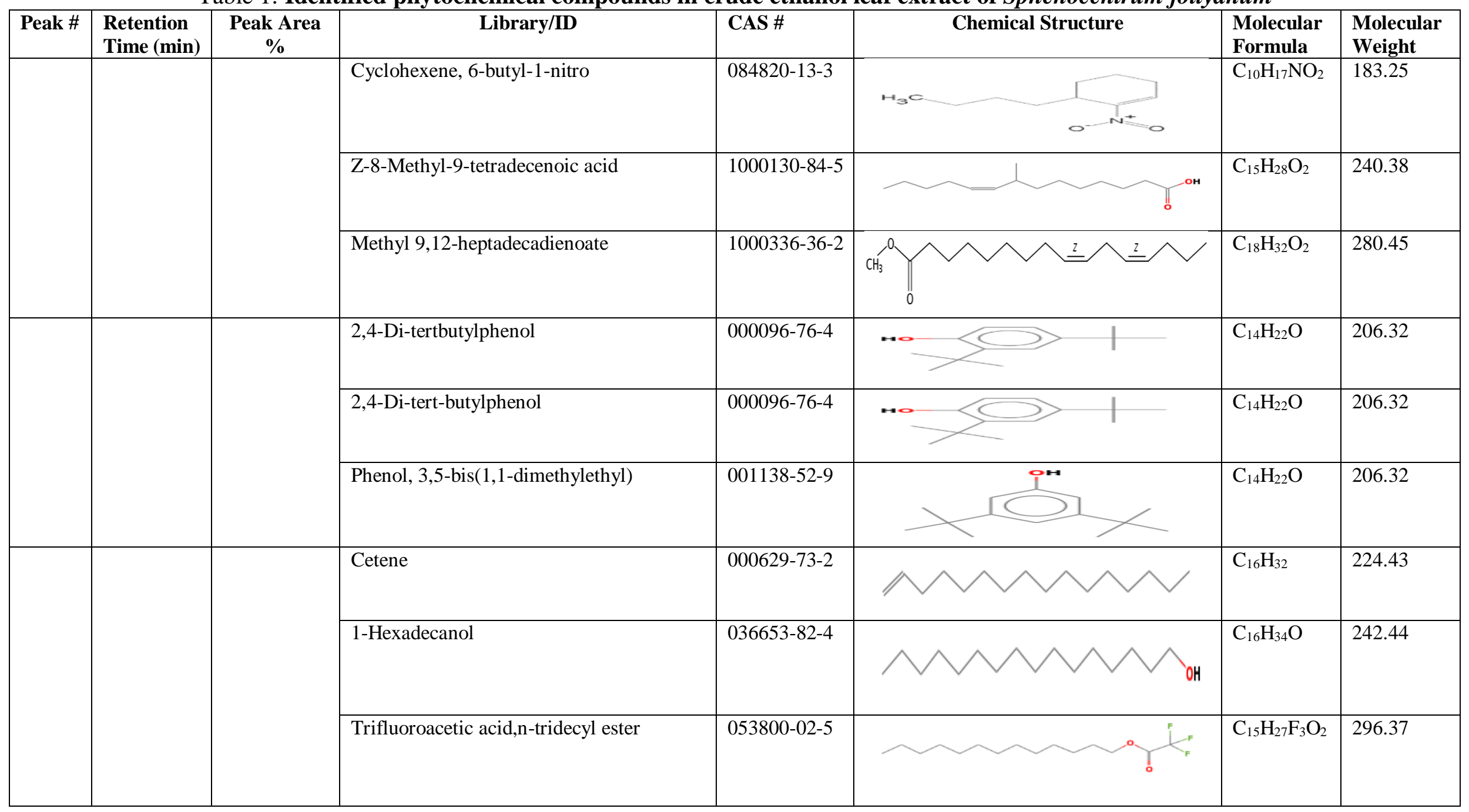


International Journal of Scientific Research in Engineering and Management (IJSREM) Volume: 06 Issue: 01 | Jan - 2022

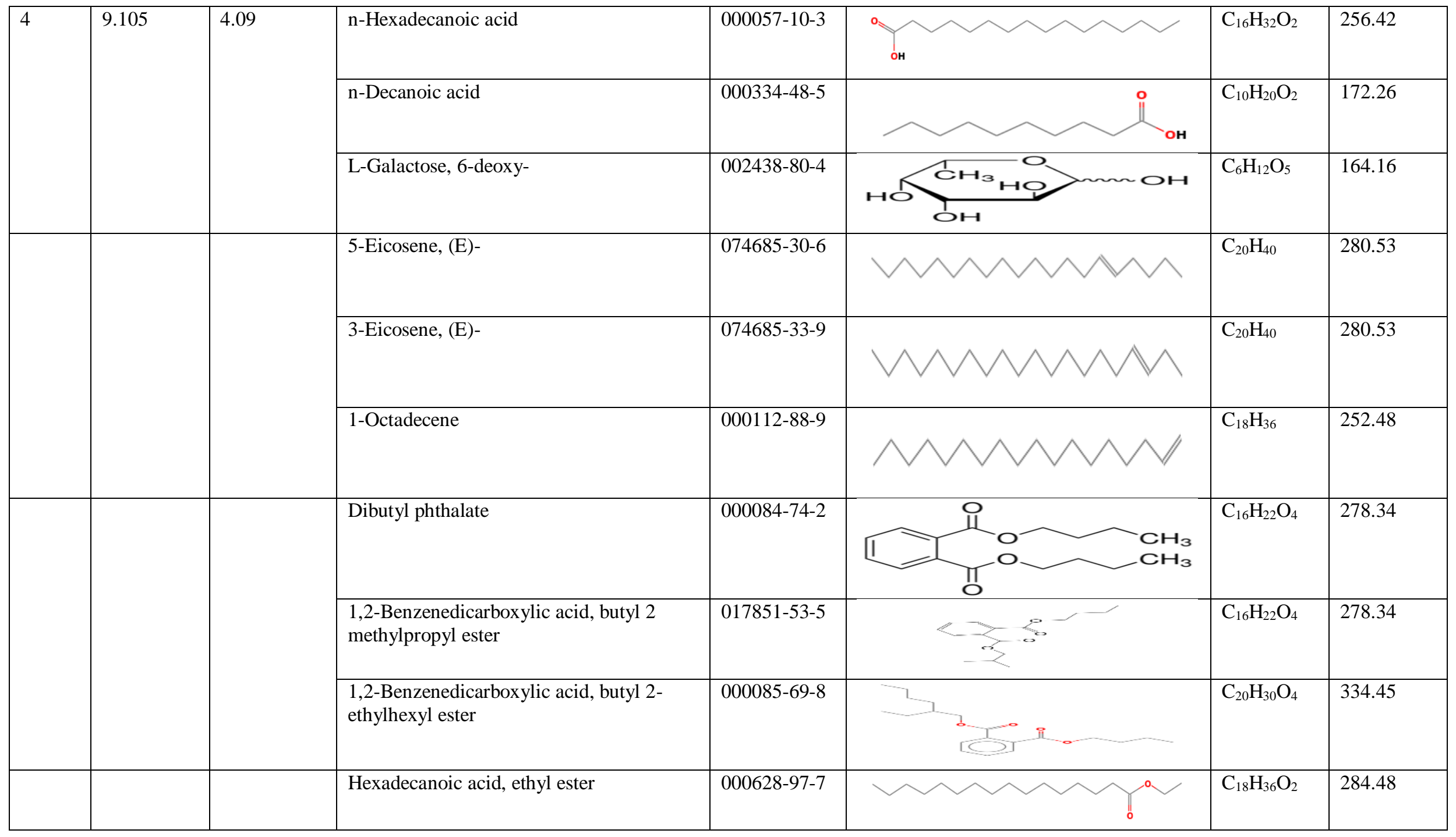


International Journal of Scientific Research in Engineering and Management (IJSREM) Volume: 06 Issue: 01 | Jan - 2022

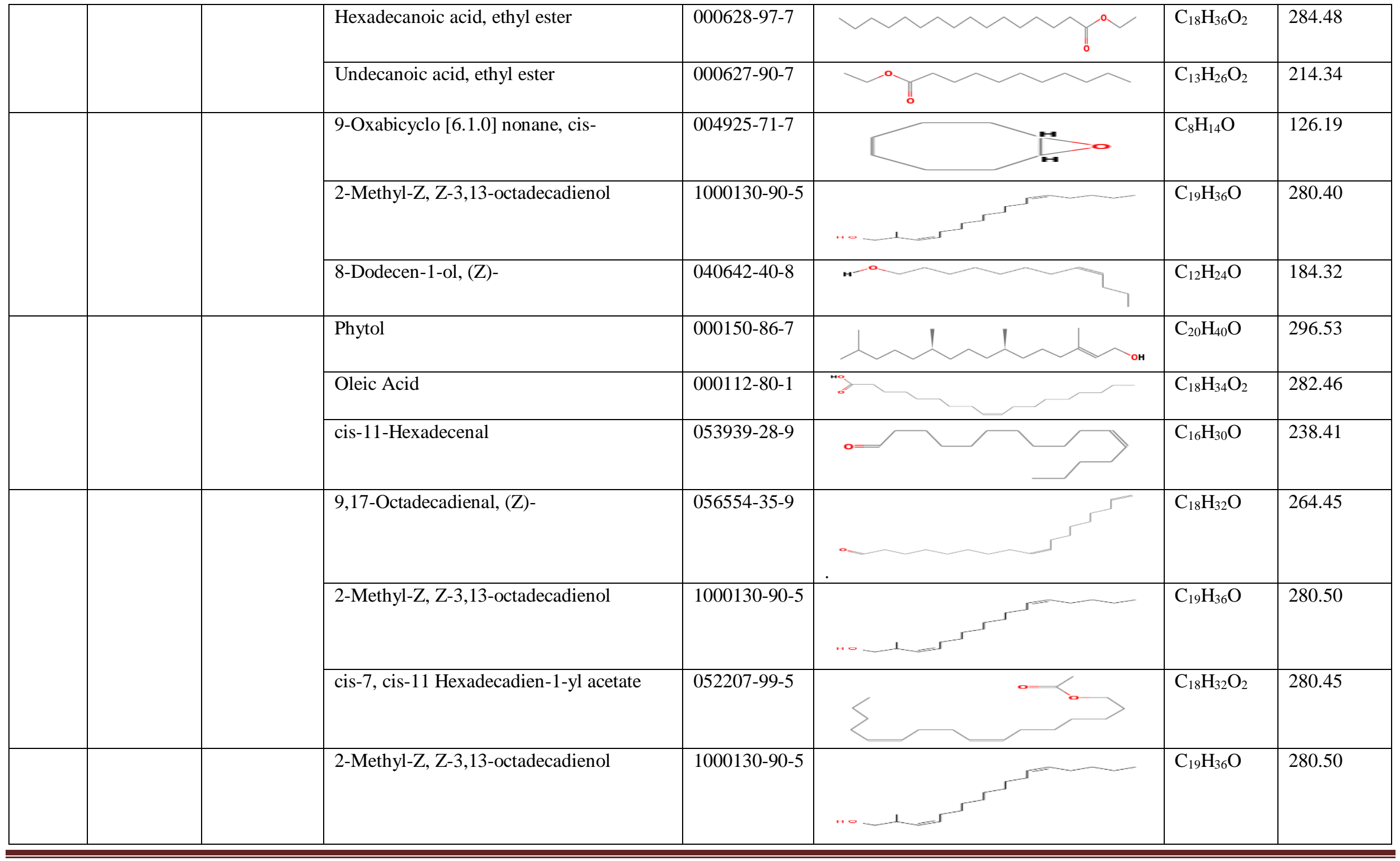




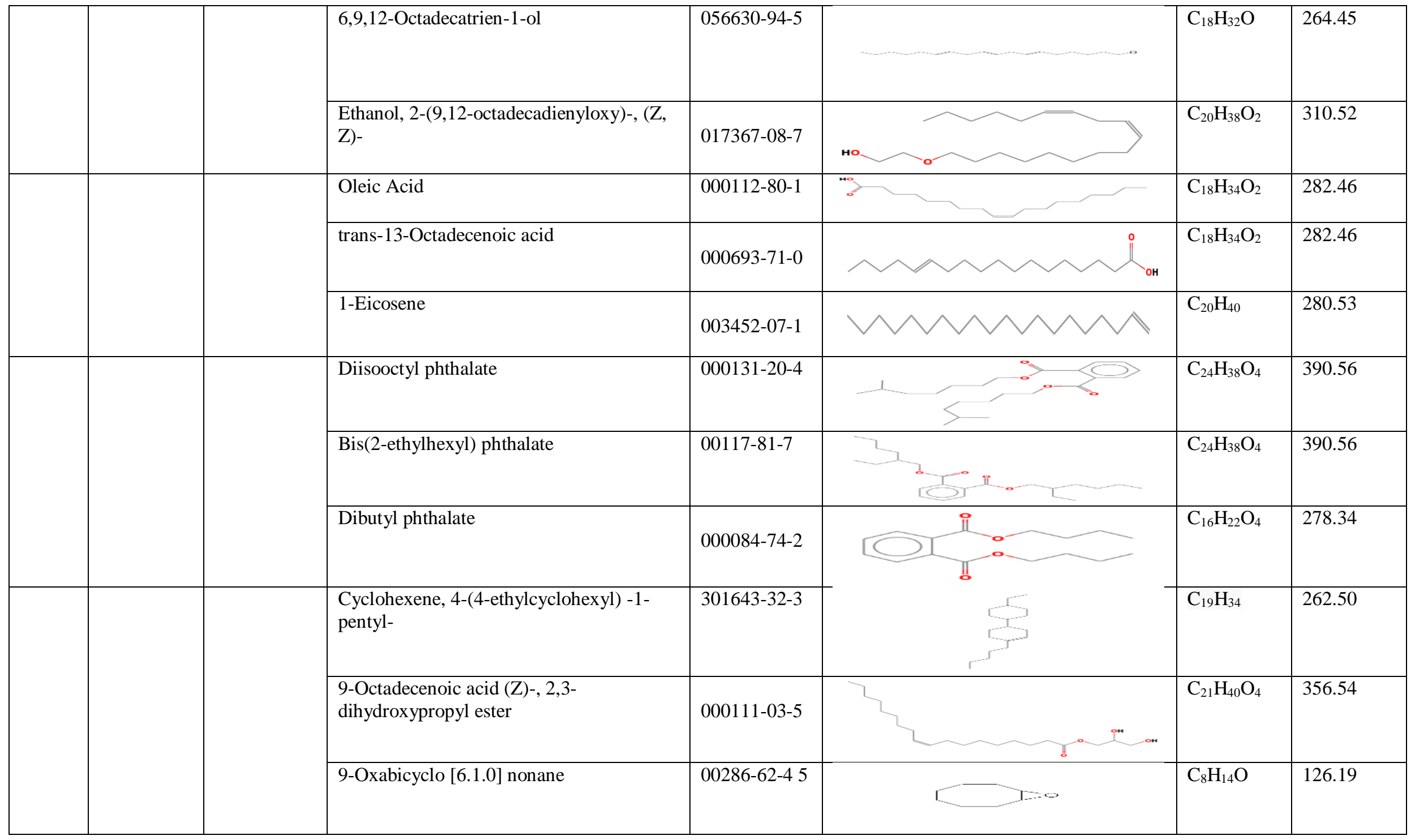




\begin{tabular}{|c|c|c|c|c|c|c|c|}
\hline \multirow[t]{4}{*}{15} & \multirow[t]{4}{*}{22.685} & \multirow[t]{3}{*}{1.47} & $\begin{array}{l}\text { 9-Octadecenoic acid (Z)-, 2-hydroxy-1- } \\
\text { (hydroxymethyl)ethyl ester }\end{array}$ & 003443-84-3 & (2) & $\mathrm{C}_{21} \mathrm{H}_{38} \mathrm{O}_{4}$ & 354.52 \\
\hline & & & 9,12-Octadecadien-1-ol, (Z, Z)- & 00506-43-4 & & $\mathrm{C}_{18} \mathrm{H}_{34} \mathrm{O}$ & 266.46 \\
\hline & & & $\begin{array}{l}\text { 9-Octadecenoic acid (Z)-, 2,3- } \\
\text { dihydroxypropyl ester }\end{array}$ & & & & \\
\hline & & Total $=99.98$ & Total compounds $=45$ & & & & \\
\hline
\end{tabular}

*Source: Dr. Duke's Phytochemical and Ethnobotanical databases (online database). 
Table 2: Bioactivity of phytocomponents identified in ethanol leaf extract of Sphenocentrum jollyanum.

\begin{tabular}{|c|c|c|c|c|}
\hline \multirow[t]{4}{*}{ S/No. } & \multirow[t]{4}{*}{ RT } & \multirow{2}{*}{$\begin{array}{l}\text { Identified Compound } \\
\text { Cyclohexene, 6-butyl-1-nitro }\end{array}$} & Nature of Compound & Reported Biological Activity \\
\hline & & & c-nitro cycloalkenes & No bioactivity reported \\
\hline & & $\begin{array}{l}\text { Z-8-Methyl-9-tetradecenoic } \\
\text { acid }\end{array}$ & Fatty acid & Antifungal (Sathya et al., 2016) \\
\hline & & $\begin{array}{ll}\text { Methyl } & 9,12- \\
\text { heptadecadienoate }\end{array}$ & Fatty acid esters & No bioactivity reported \\
\hline & & 2,4-Di-tert-butylphenol & Phenylpropane & Antibacterial, Antioxidant (Ndiege et al.2021) \\
\hline & & $\begin{array}{l}\text { Phenol,3,5-bis(1,1- } \\
\text { dimethylethyl) }\end{array}$ & Phenylpropane & Antioxidant (Ndiege et al.2021) \\
\hline & & Cetene & Aliphatic & Antitumor and Antioxidant (Sunil et al.,2018) \\
\hline & & 1-Hexadecanol & Fatty alcohol & $\begin{array}{l}\text { Antioxidant, opacifier, emulsifier, and thickening agent, } \\
\text { emollient (Amudha } \text { et al., 2018) }\end{array}$ \\
\hline & & $\begin{array}{l}\text { Trifluoroacetic acid, } \mathrm{n}- \\
\text { tridecyl ester }\end{array}$ & Fatty acid ester & $\begin{array}{l}\text { Anti-inflammatory, antiarthritic, antimicrobial, anti- } \\
\text { tumour, antiprotozoal and chemopreventive (Kalaivani et } \\
\text { al., 2018) }\end{array}$ \\
\hline & & n-Decanoic acid & Fatty acid & Antifungal (Sathya et al., (2016). \\
\hline & & n-Hexadecanoic acid & Fatty acid & $\begin{array}{l}\text { antioxidant, hypocholesterolemic, nematicide, pesticide, } \\
\text { lubricant, antiandrogenic, flavour, hemolytic and 5- } \\
\text { alpha, reductase inhibitor Pauldasan } \text { et al., 2020. } \\
\text { Potent mosquito larvicide (Abubakar and Majinda, } \\
\text { 2016), Anticancer, Antipesticide, Antimicrobial } \\
\text { (Hameed et al., 2015). }\end{array}$ \\
\hline & & L-Galactose, 6-deoxy- & Sugar moiety & Flavouring agent (Azhagu,2021) \\
\hline & & 5-Eicosene, $(\mathrm{E})-$ & Fatty acid & antimicrobial activity (Yogeswari et al., 2012) \\
\hline & & 3-Eicosene, $(\mathrm{E})$ - & Fatty acid & $\begin{array}{l}\text { Antimicrobial, Antihyperglycemic, Cytotoxic Activity, } \\
\text { Antioxidant, Insecticidal activity (Banakar and Jayaraj, } \\
\text { 2018) }\end{array}$ \\
\hline & & 1-Octadecene & Alkene & Antibacterial, antioxidant (Indra et al., 2018) \\
\hline & & Dibutyl phthalate & Plasticizer compound & $\begin{array}{l}\text { Antimicrobial, Antifouling (G. GnanaPriyanka Beulah } \\
\text { et.al.2018) }\end{array}$ \\
\hline & & $\begin{array}{l}\text { 1,2-Benzenedicarboxylic } \\
\text { acid, butyl } 2 \text { methyl propyl } \\
\text { ester }\end{array}$ & Phthalate ester & $\begin{array}{l}\text { Hypoglycemic Effect; } \alpha \text {-glucosidase inhibitor (Bu et al., } \\
\text { 2010) }\end{array}$ \\
\hline & & $\begin{array}{l}\text { 1,2-Benzenedicarboxylic } \\
\text { acid, butyl 2-ethylhexyl ester }\end{array}$ & Ester & $\begin{array}{l}\text { antitumor activity; pro-inflammatory agent (El-Sayed et } \\
\text { al., 2015). Antioxidant and/ or renal protective activity } \\
\text { (Adeyemi et al. (2017) }\end{array}$ \\
\hline & & $\begin{array}{l}\text { Hexadecanoic acid, ethyl } \\
\text { ester }\end{array}$ & Fatty acid ester & $\begin{array}{l}\text { Antioxidant, flavour, hypocholesterolemic, nematicide, } \\
\text { pesticide, lubricant, antiandrogenic, hemolytic, 5-alpha } \\
\text { reductase inhibitor (Adeniyi et al., 2019) }\end{array}$ \\
\hline & & Undecanoic acid, ethyl ester & Fatty acid esters & $\begin{array}{lcc}\text { Antioxidant, Increase Aromatic Amino } & \text { acid } \\
\text { decarboxylase activity (Juliet et al., (2020). } & \end{array}$ \\
\hline & & $\begin{array}{l}\text { 9-Oxabicyclo [6.1.0] nonane, } \\
\text { cis- }\end{array}$ & Terpenoids & $\begin{array}{l}\text { antibacterial, Anti-fungal and nematicidal activity } \\
\text { (Sathya et al., (2016). }\end{array}$ \\
\hline & & $\begin{array}{l}\text { 2-Methyl-Z, } \\
\text { octadecadienol }\end{array}$ & Aliphatic Alcohol & $\begin{array}{l}\text { Anticancer, Anti-microbial, Cytotoxic } \\
\text { (Vikrama et al., 2018; Yirankinyuki et al. 2020) }\end{array}$ \\
\hline
\end{tabular}




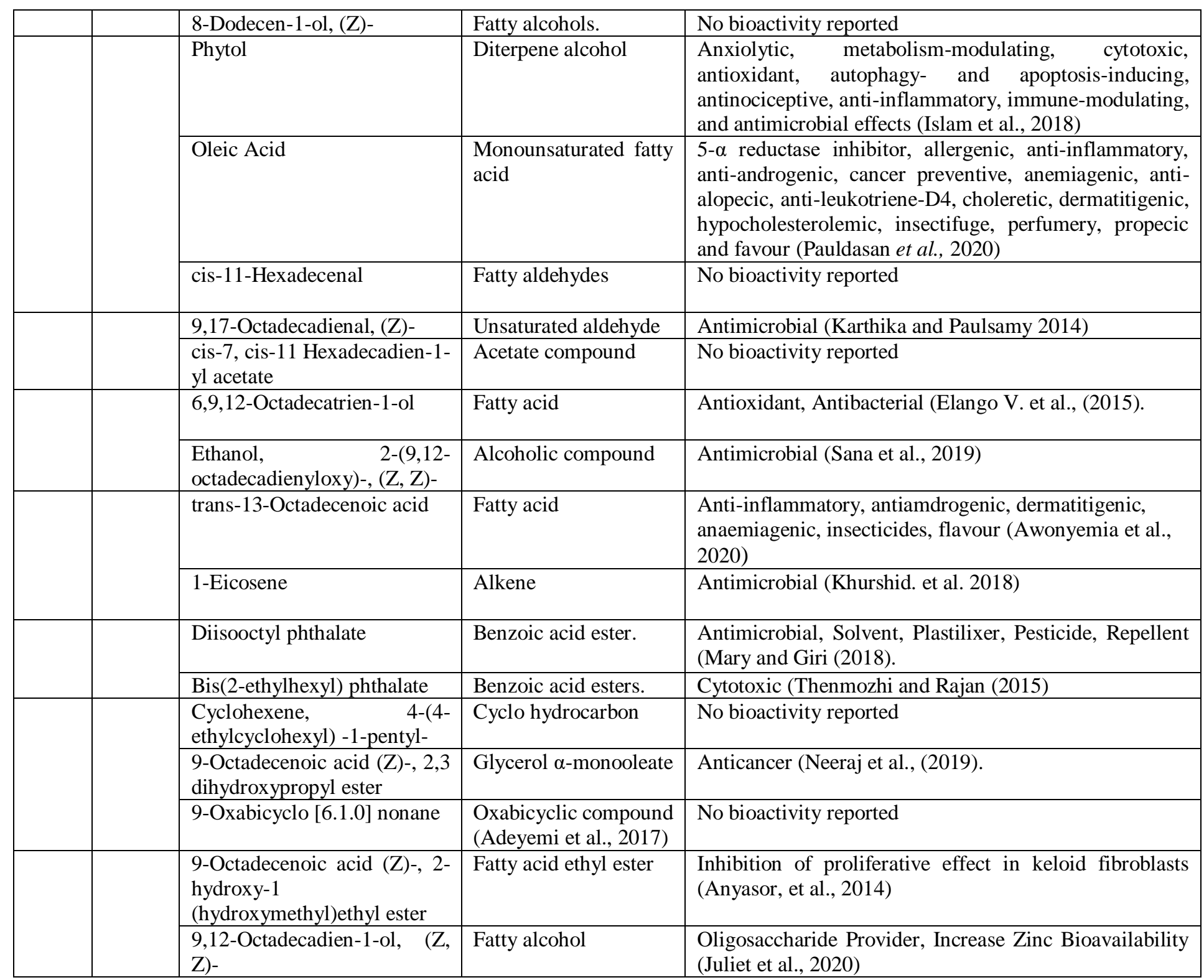

RT: Retention time 


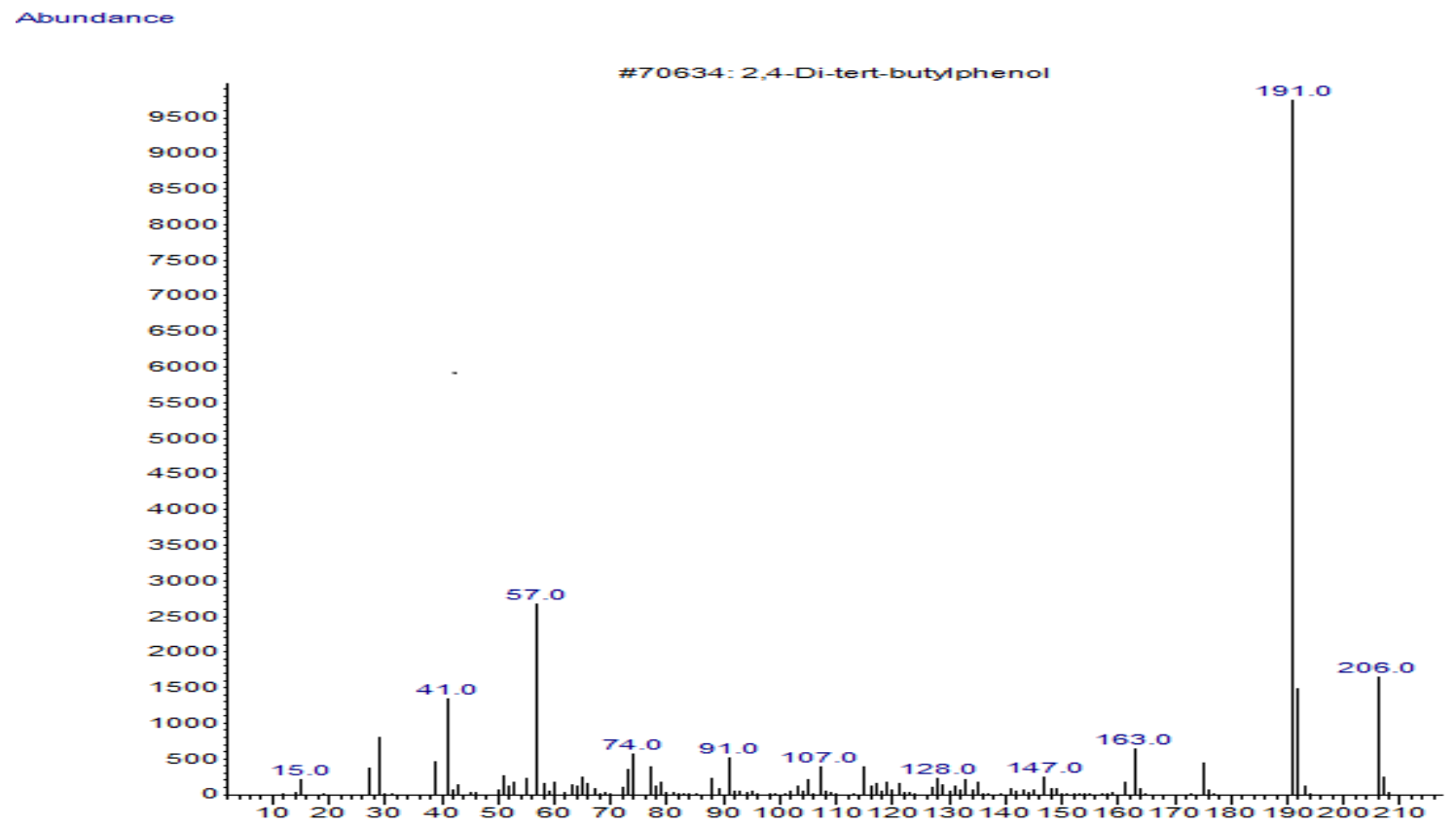

Figure 3: GC-MS spectra of 2,4-Di-tertbutylphenol (RT: 7.243, 21.05\%) from Sphenocentrum jollyanum leaf extract.

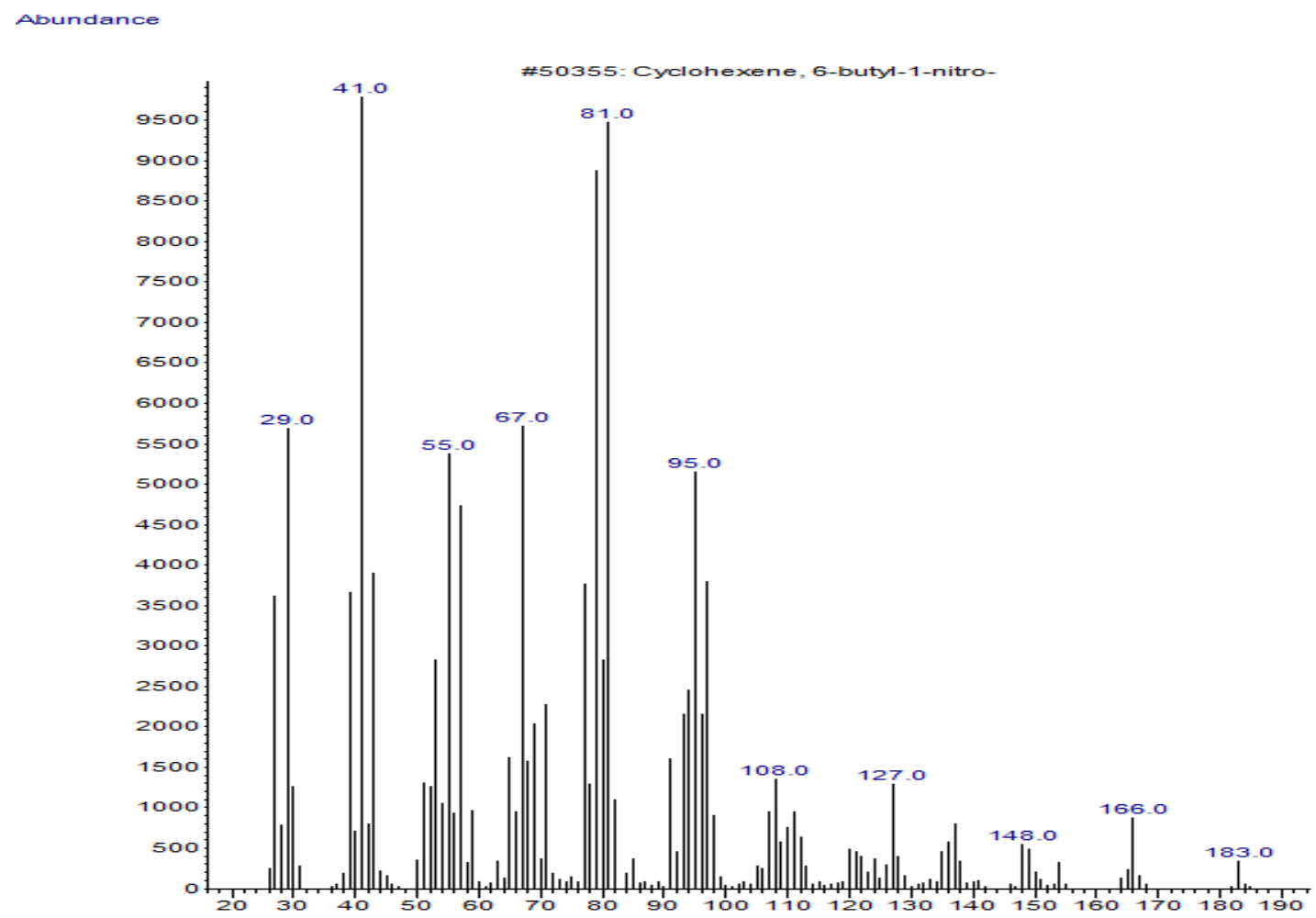

$m z z-\infty$

Figure 4: GC-MS spectra of Cyclohexene, 6-butyl-1-nitro (RT:5.255, 19.12\%) from Sphenocentrum jollyanum leaf extract. 


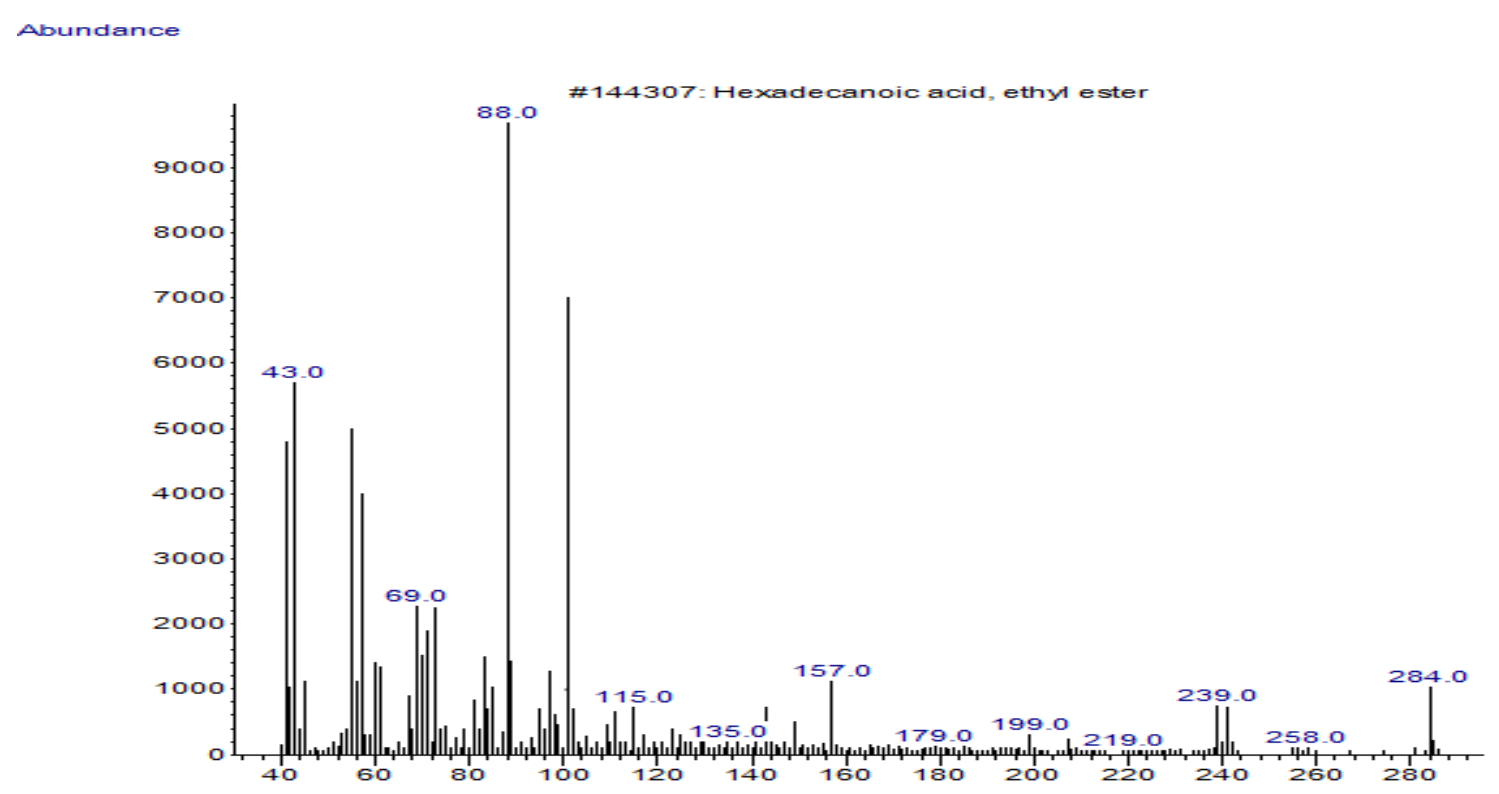

$m v z->$

Figure 5: GC-MS spectra of Hexadecanoic acid, ethyl ester (RT: 12.678,7.86\%) from Sphenocentrum jollyanum leaf extract.

Abundance

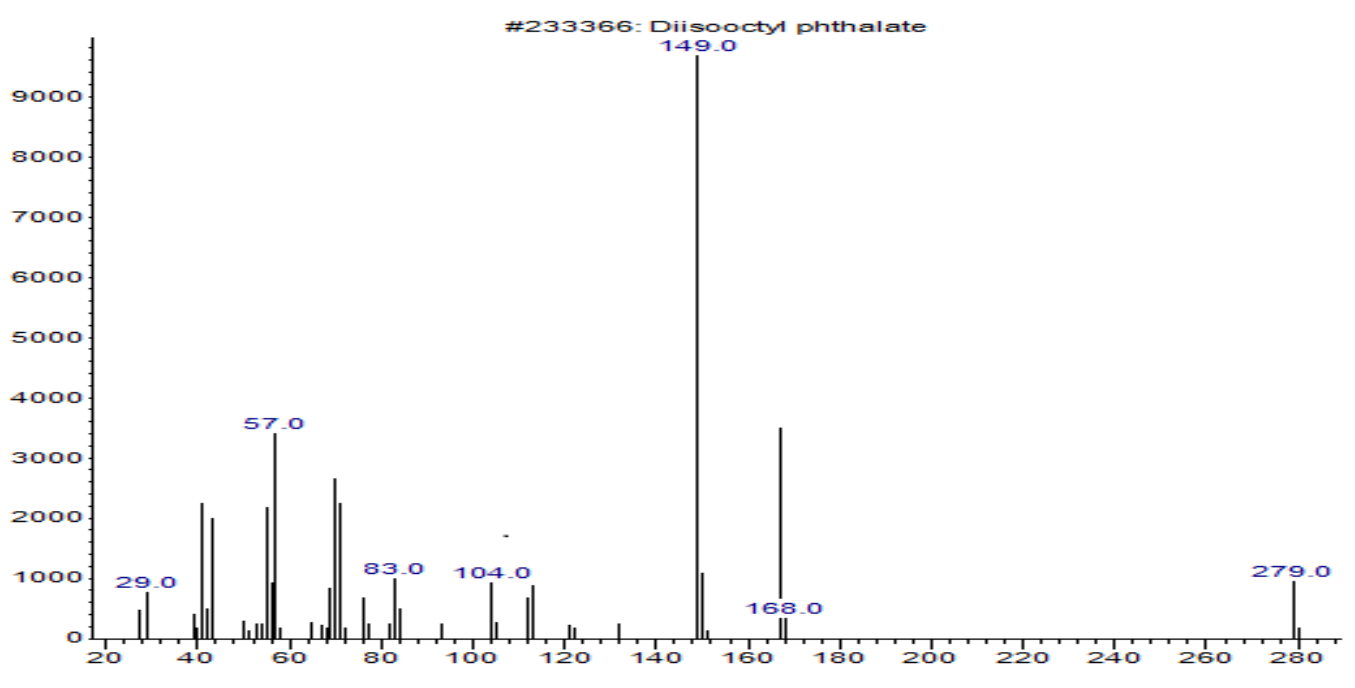

$m v z->$

Figure 6: GC-MS spectra of Diisooctyl phthalate (RT: 20.391, 7.13\%) from Sphenocentrum jollyanum leaf extract. 
Abundance

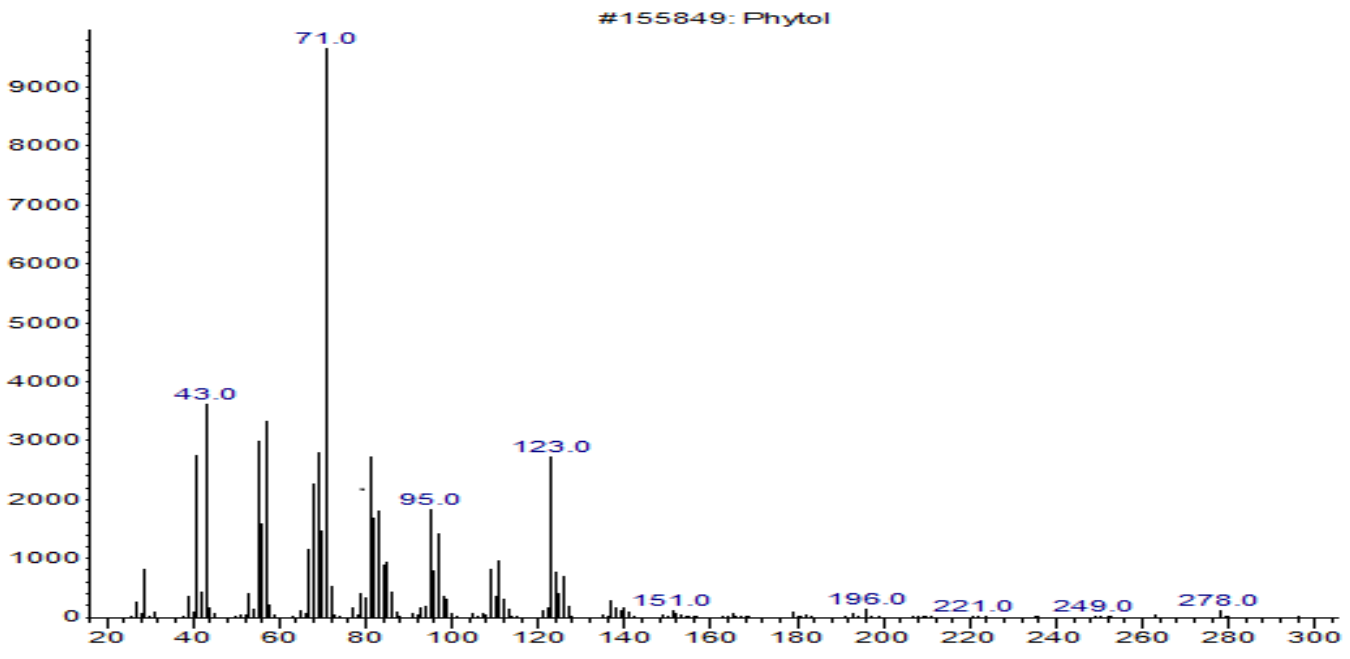

$m v z->$

Figure 7: GC-MS spectra of Phytol (RT: 14.246, 7.03\%) from Sphenocentrum jollyanum leaf extract.

Abundance

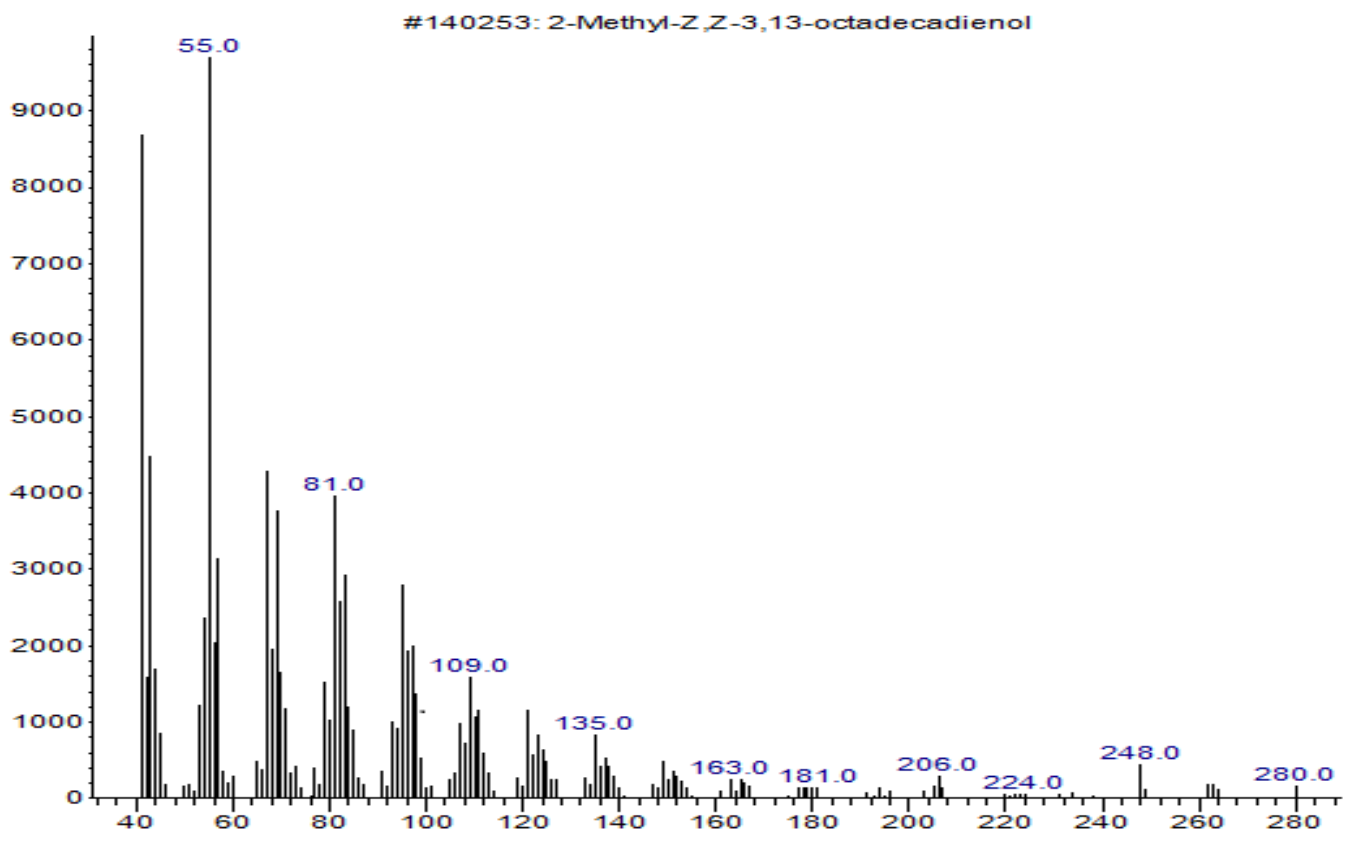

$m / z->$

Figure 8: GC-MS spectra of 2-Methyl-Z, Z-3,13-octadecadienol (RT: 14.946, 6.65\%) from Sphenocentrum jollyanum leaf extract. 
Abundance

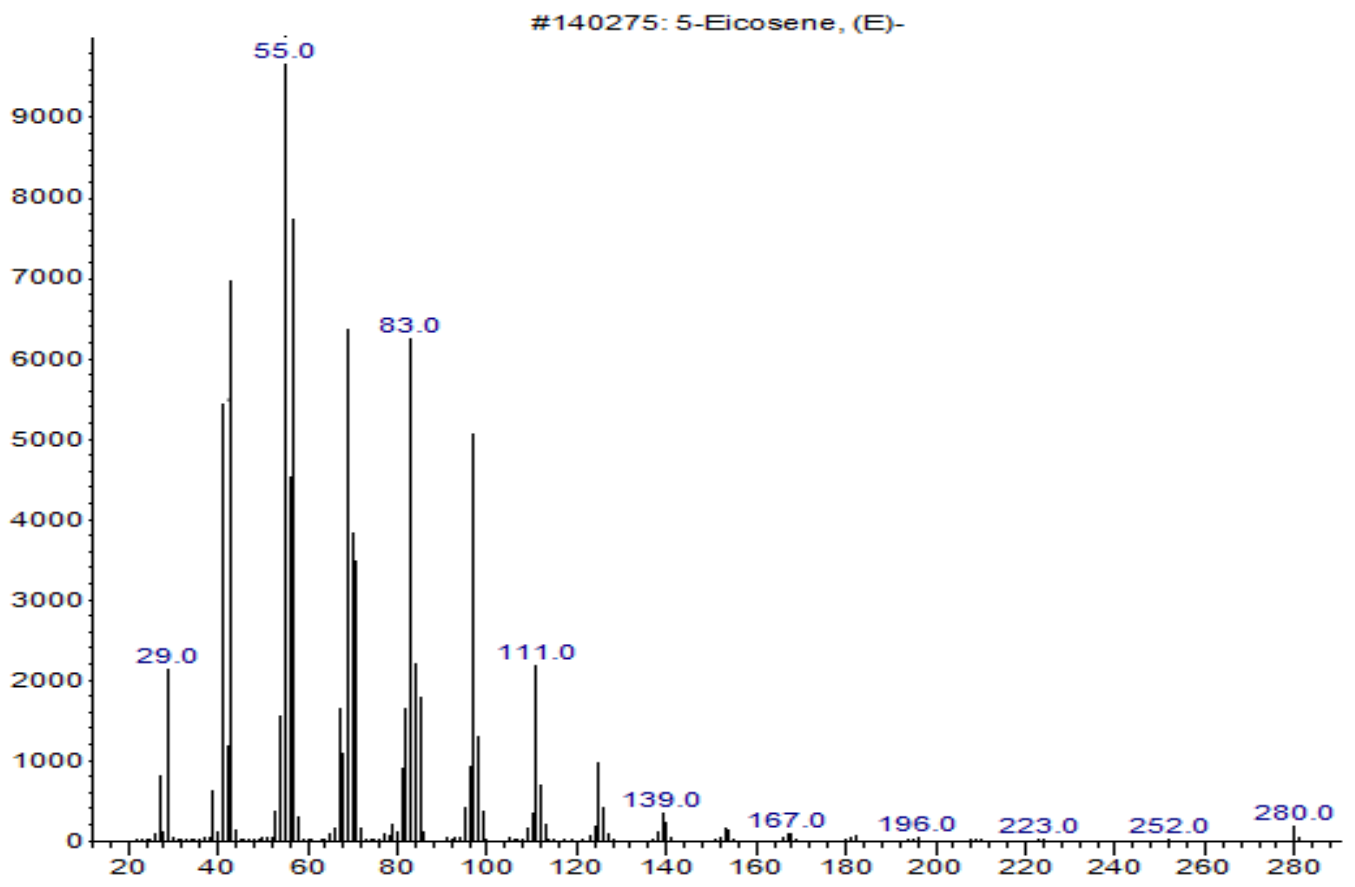

$\mathrm{m} v z->$

Figure 9: GC-MS spectra of 5-Eicosene, (E)- (RT: 10.372, 4.63\%) from Sphenocentrum jollyanum leaf extract

Abundance

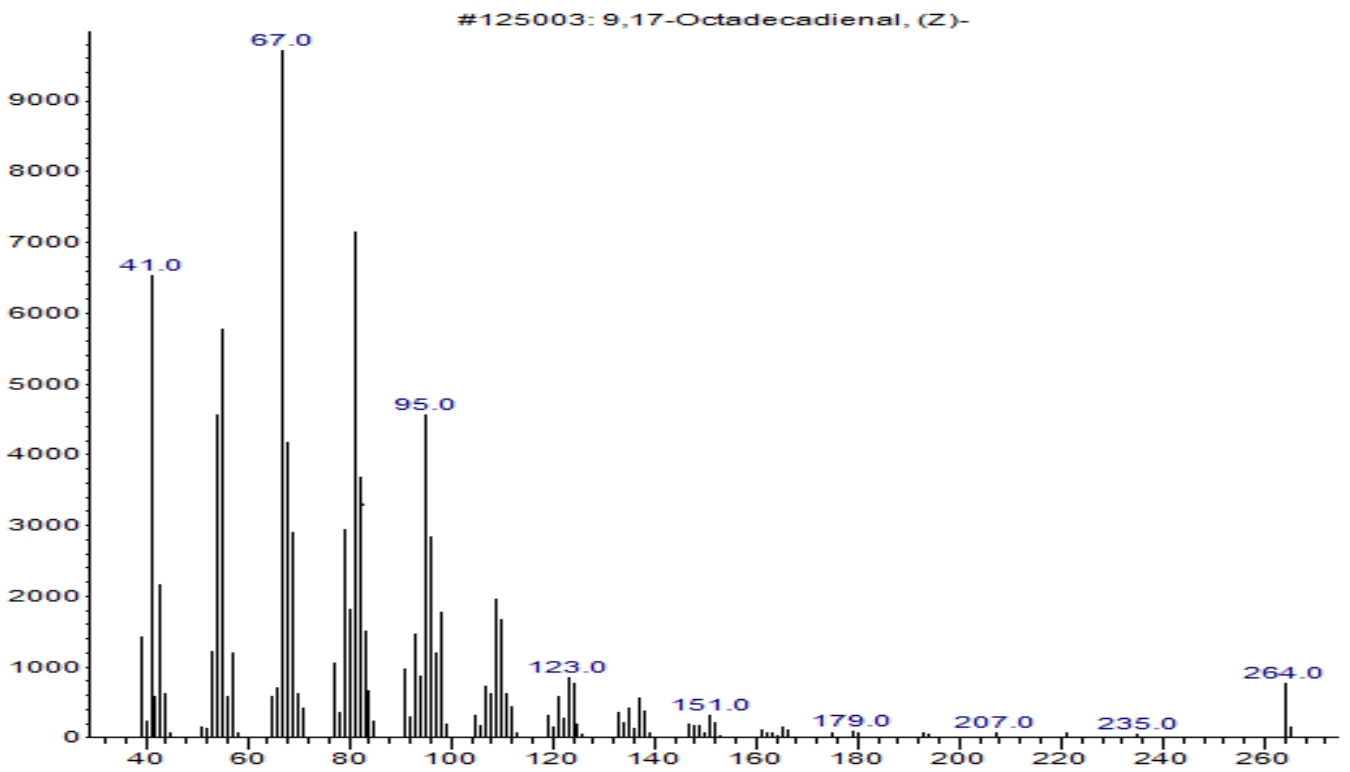

$m v z-->$

Figure 10: GC-MS spectra of 9,17-Octadecadienal, (Z)- (RT: 14.857, 4.24\%) from Sphenocentrum jollyanum leaf extract. 
Abundance

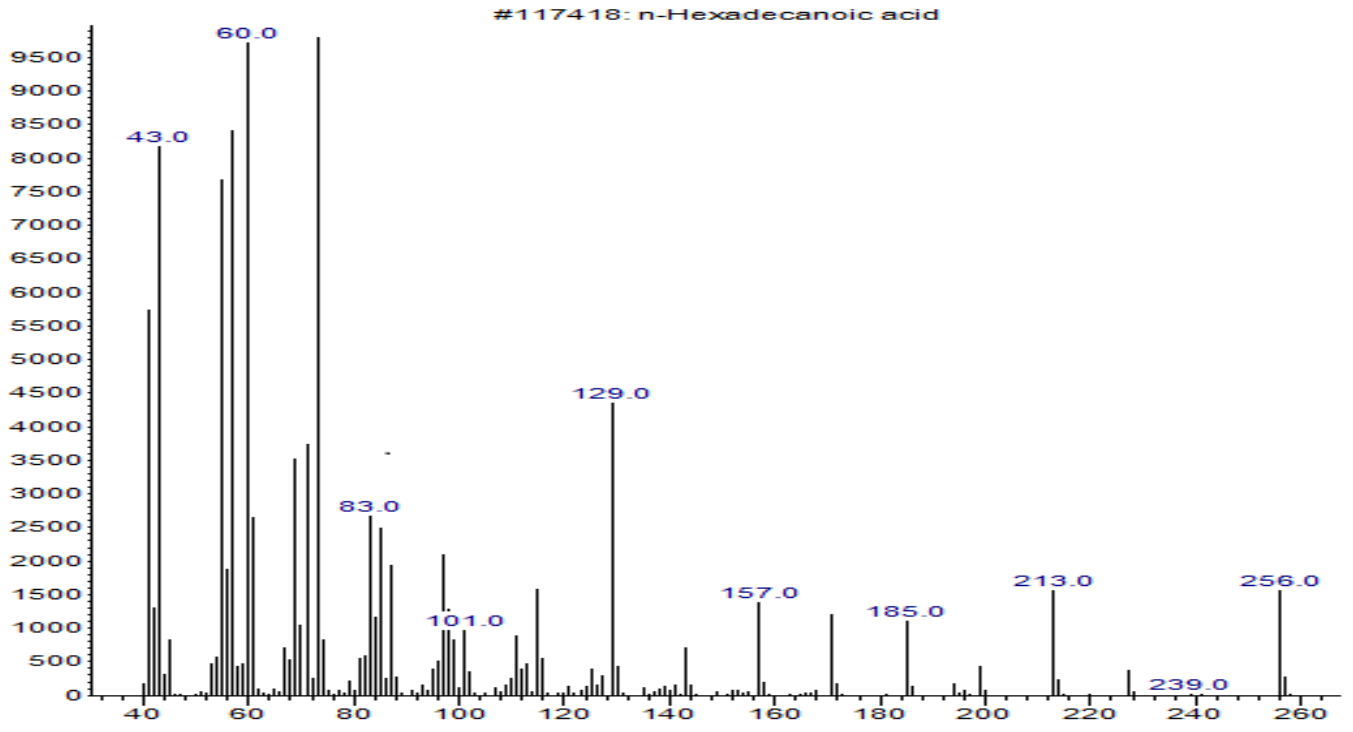

$m v z-1=$

Figure 11: GC-MS spectra of n-Hexadecanoic acid (RT:9.105, 4.09\%) from Sphenocentrum jollyanum leaf extract

Abundance

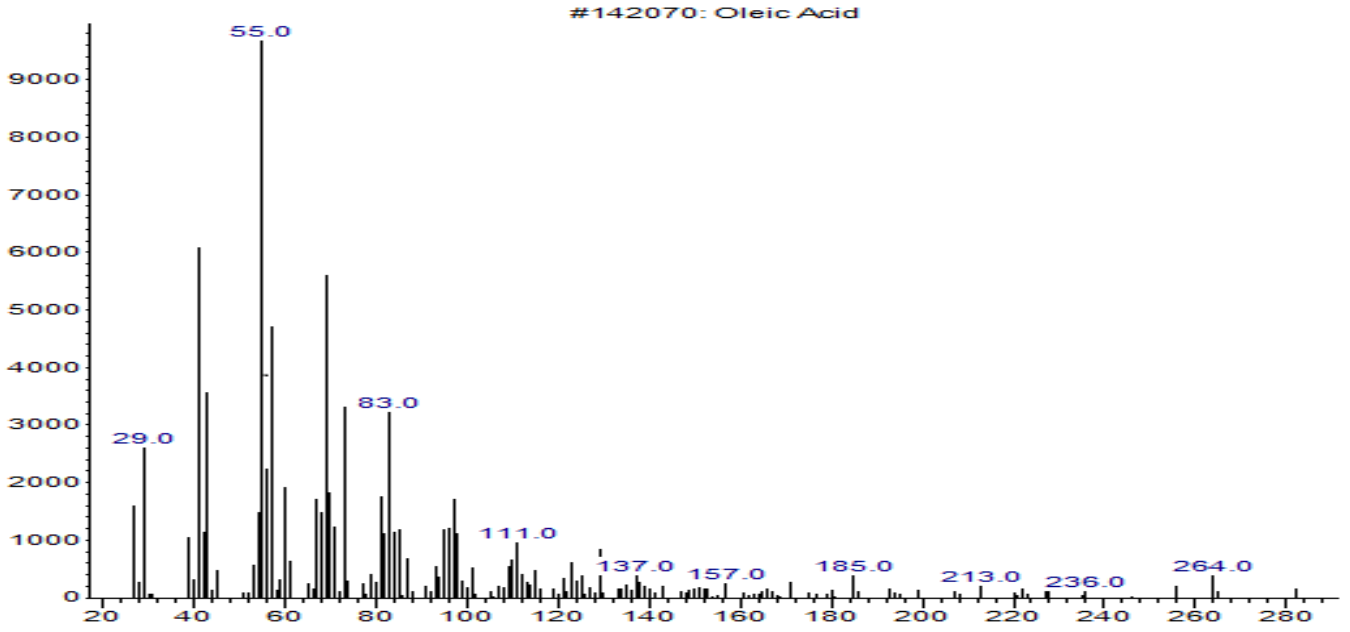

$m z z-1$

Figure 12: GC-MS spectra of Oleic Acid (RT: 15.261, 3.81\%) from Sphenocentrum jollyanum leaf extract. 


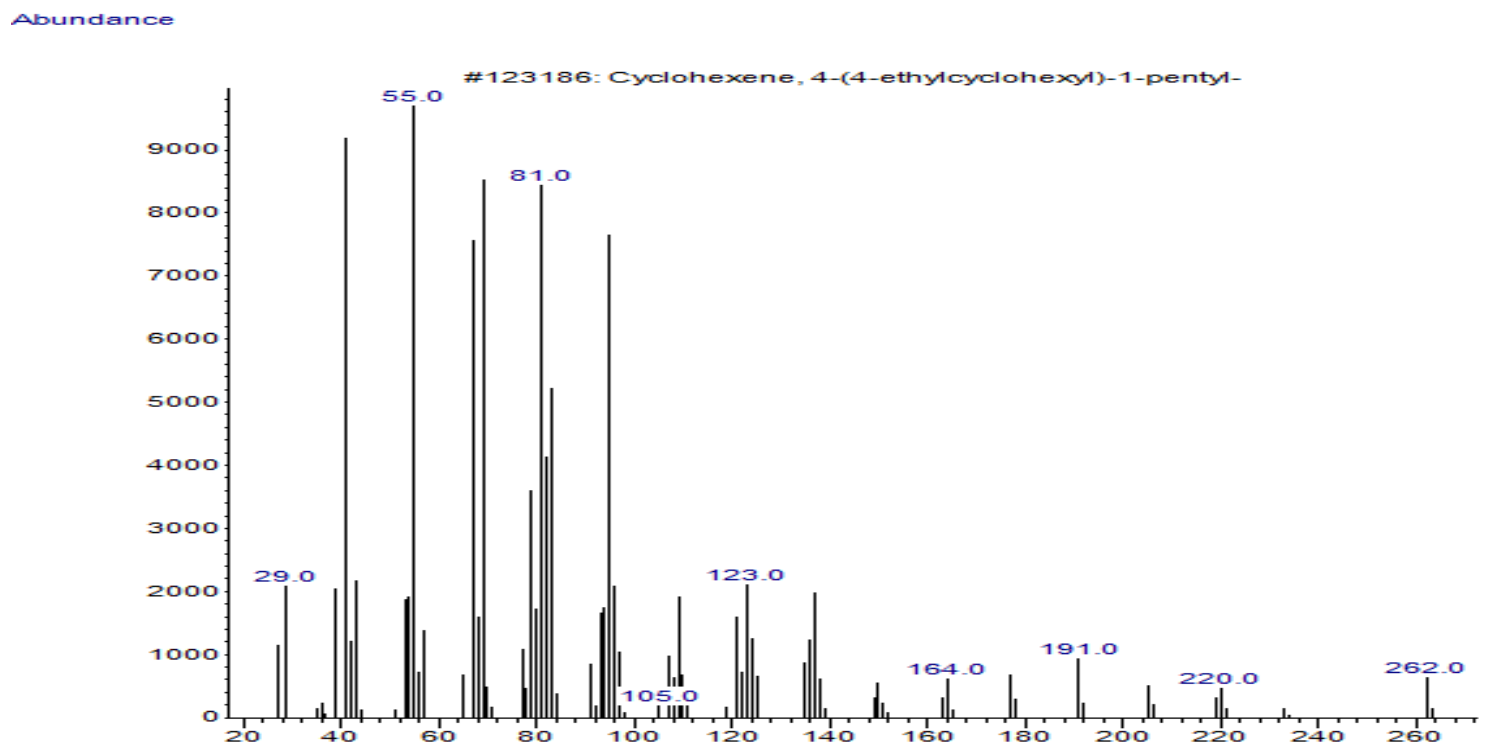

Figure 13: GC-MS spectra of Cyclohexene, 4-(4-ethylcyclohexyl) -1-pentyl- (RT: 22.648, 3.74\%) from Sphenocentrum jollyanum leaf extract.

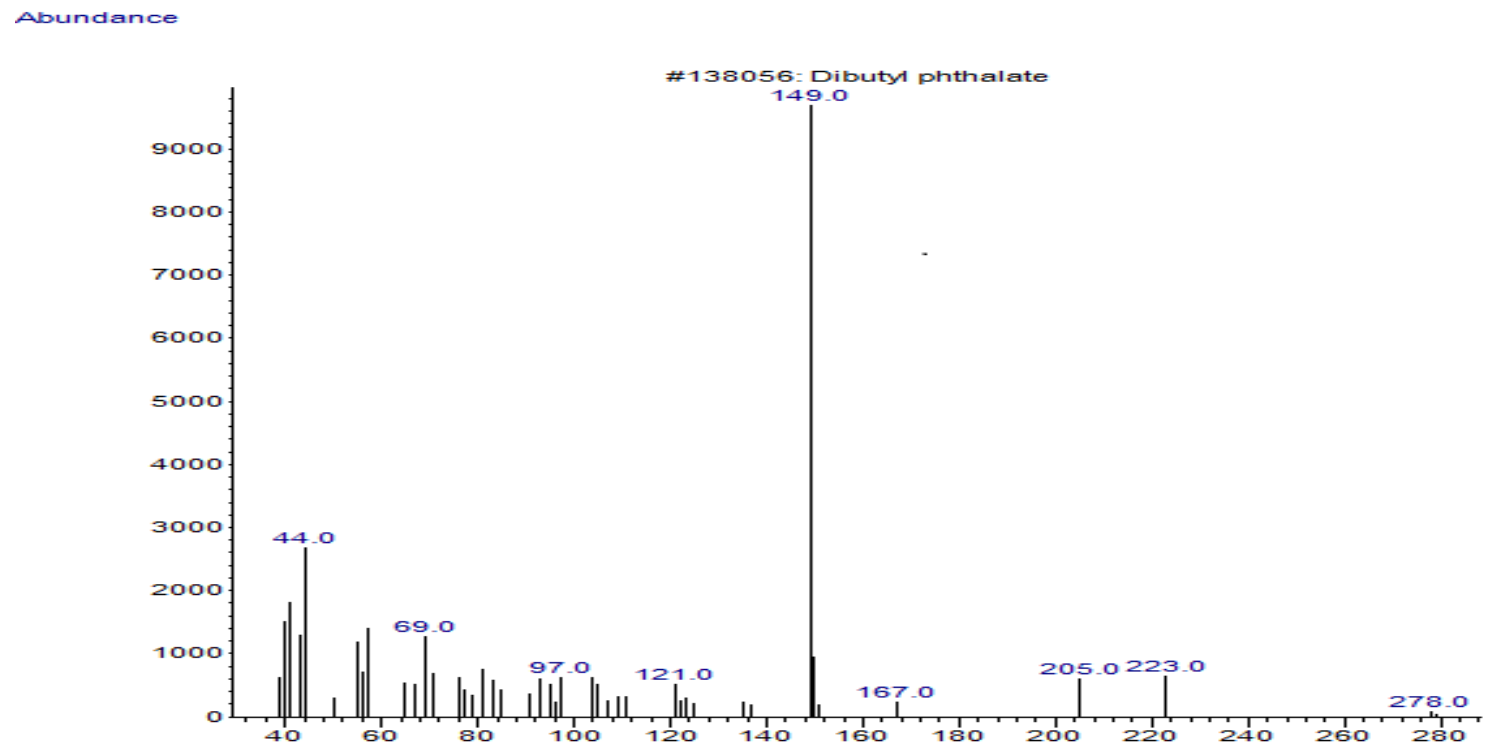

$m z-->$

Figure 14: GC-MS spectra of Dibutyl phthalate (RT: 12.426, 3.20\%) from Sphenocentrum jollyanum leaf extract 


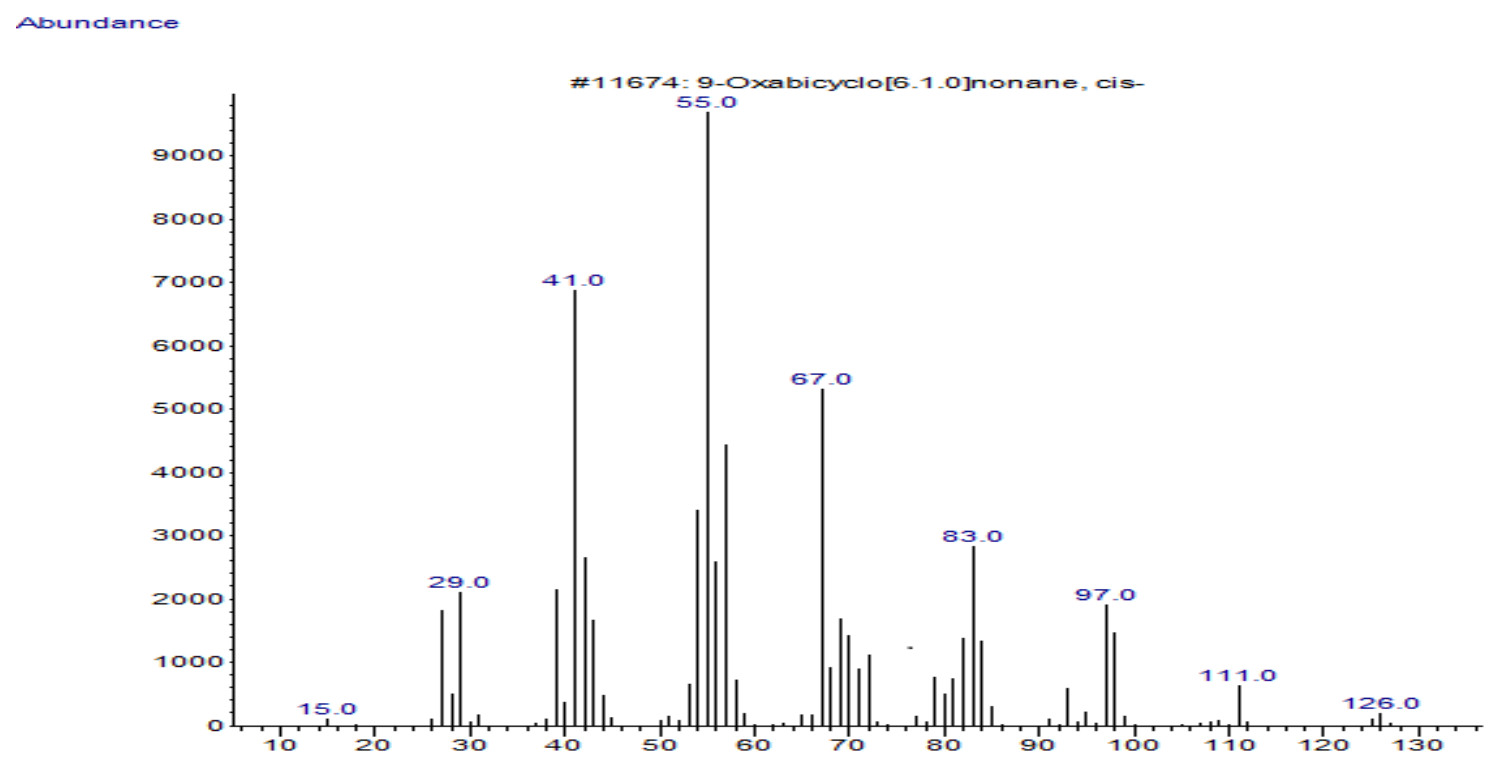

$m / z->$

Figure 15: GC-MS spectra of 9-Oxabicyclo [6.1.0] nonane, cis- (RT: 14.046,3.18\%) from Sphenocentrum jollyanum leaf extract.

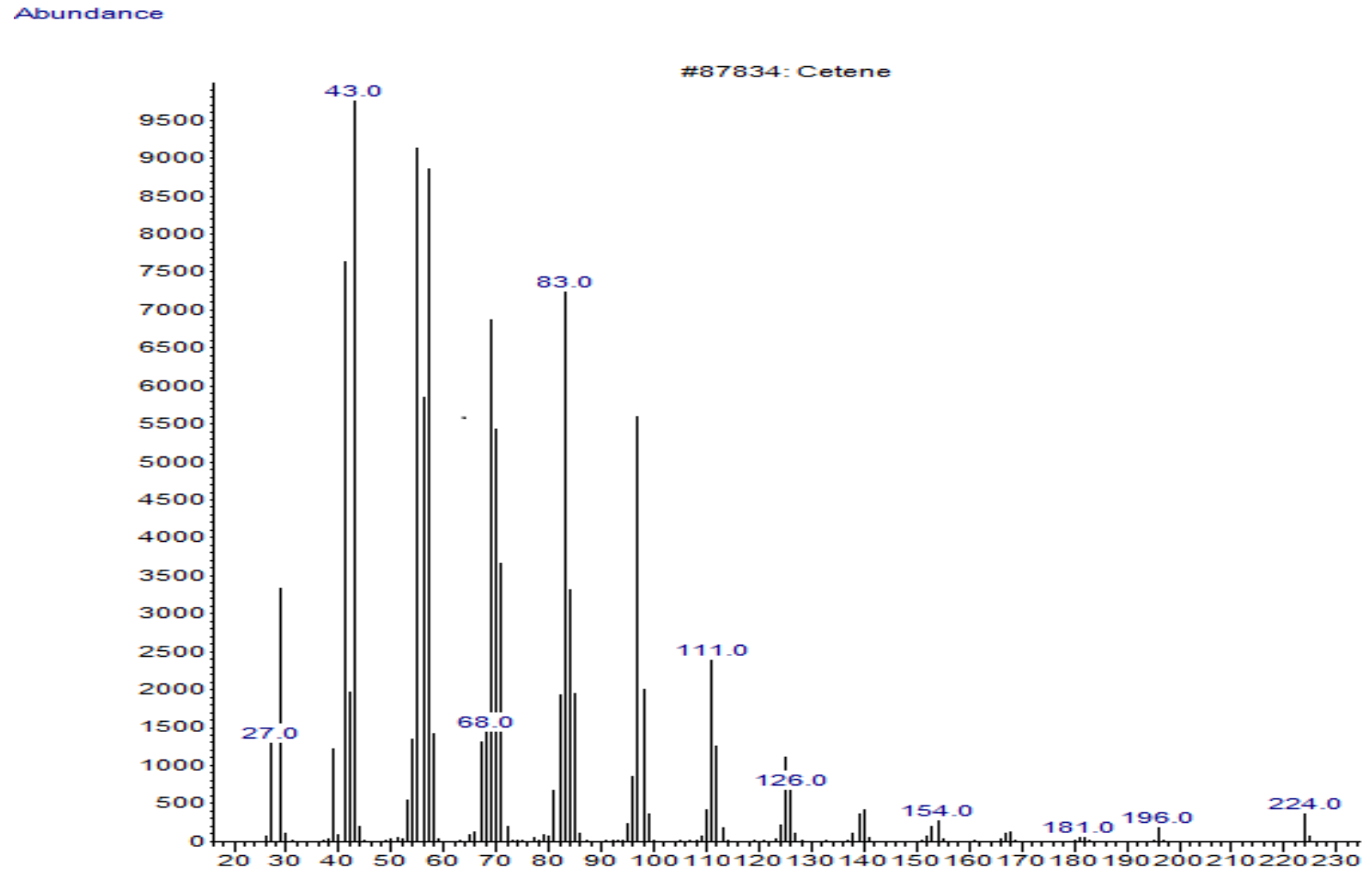

$m v z--=$

Figure 16: GC-MS spectra of cetene (RT:8.017, $2.78 \%)$ from Sphenocentrum jollyanum leaf extract. 
Abundance

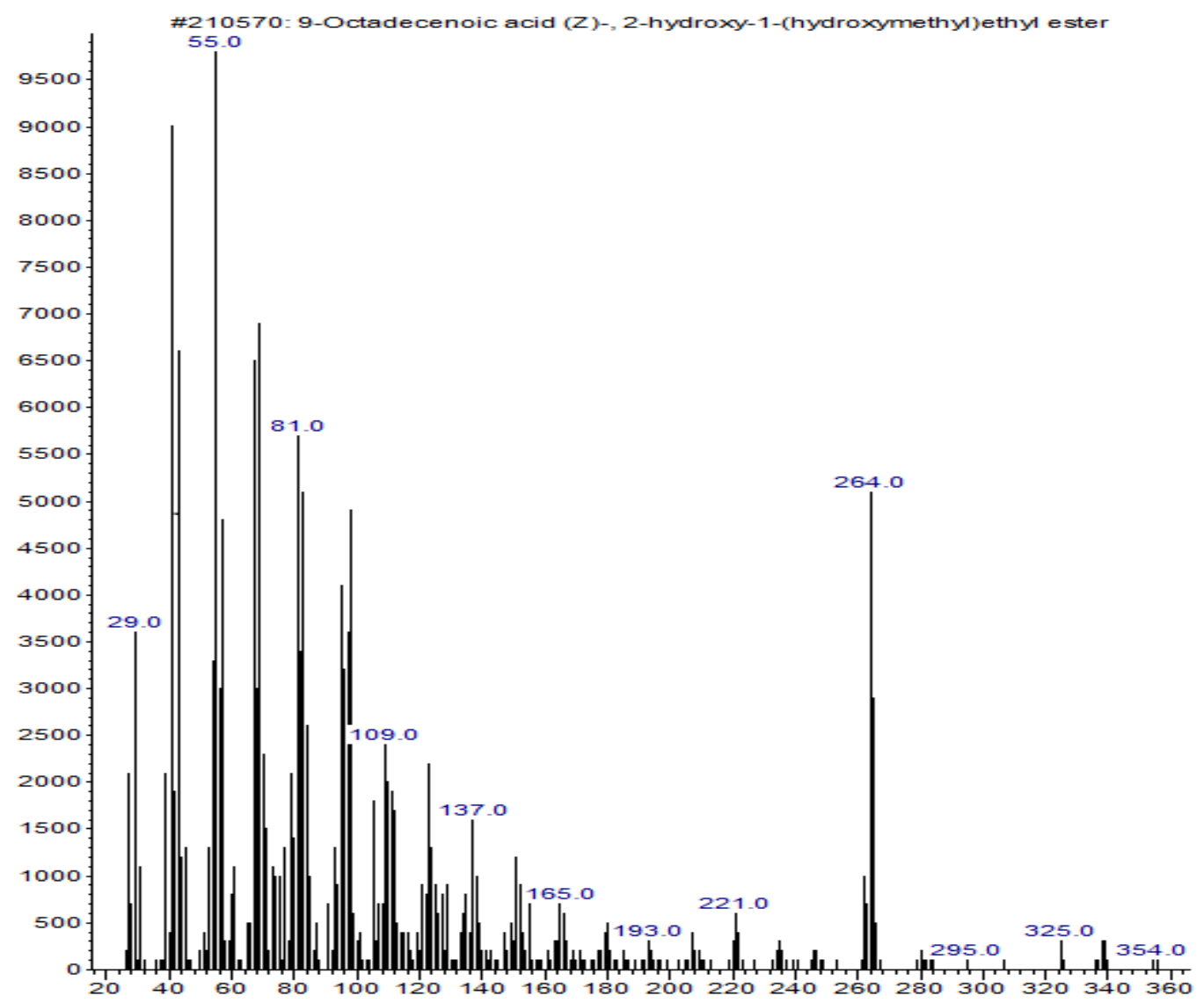

$m v z-->$

Figure 17: GC-MS spectra of 9-Octadecenoic acid (Z)-, 2-hydroxy-1-(hydroxymethyl) ethyl ester (RT: 22.685, 1.47\%) from Sphenocentrum jollyanum leaf extract.

\section{DISCUSSION}

Gas Chromatography-Mass Spectrometry (GC-MS) is a hybrid analytical technique that combines the separation properties of gas-liquid chromatography with the detection feature of mass spectrometry to identify different substances within a test sample. GC is used to separate the volatile and thermally stable substitutes in a sample whereas MS helps fragment the analyte to be identified on the basis of its mass(Sahil et al., 2011; Jenke, 1996). GC-MS provides enhanced sample identification, higher sensitivity, an increased range of analyzable samples, and faster results, which enable a whole new range of applications for GC-MS in several areas ( Susha, 2019).

In the present study, the GC-MS chromatogram detected 15 peaks representing 45 compounds from the ethanol leaf extract of Sphenocentrum jollyanum (Table 1., Figure 1). Among the identified bioactive components, 2,4- 
Di-tert-butylphenol, also known as 2,4-DTBP and Phenol, 3,5-bis(1,1-dimethylethyl) with retention time (RT) of 7.243 has the highest peak area of $21.05 \%$. They belong to the class of organic compounds known as phenylpropanes. They have antibacterial and antioxidant properties. They are used industrially as UV stabilizers and as antioxidants for hydrocarbon-based products ranging from petrochemicals to plastics. They have also been reported to prevents gumming in aviation fuels (Ndiege et al.2021).

Z-8-Methyl-9-tetradecenoic acid with RT of 5.255 and a peak area of $19.12 \%$ has antifungal properties (Sathya et al., 2016).

Hexadecanoic acid, ethyl ester and Undecanoic acid, ethyl ester are fatty acid esters. They have RT of 12.678 with a peak of $7.86 \%$. Hexadecanoic acid, ethyl ester has antioxidant, flavour, hypocholesterolemic, nematicide, pesticide, lubricant, antiandrogenic, hemolytic, 5-alpha reductase inhibitor (Adeniyi et al., 2019) while Undecanoic acid, ethyl ester exhibits antioxidant, and increases aromatic amino acid decarboxylase activity (Juliet et al., (2020).

Di-iso-octyl phthalate, and Bis(2-ethylhexyl) phthalate are a class of organic compounds known as benzoic acid esters. It has a RT of 20.391 and peak of 7.13\%. Di-iso-octyl phthalate has been reported to possess antimicrobial, solvent, plasticizer, pesticide, repellent (Mary and Giri (2018). Bis(2-ethylhexyl) phthalate is a primary metabolite that are directly involved in an organism's growth, development or reproduction and are potentially toxic compound. Thenmozhi and Rajan (2015) reported the cytotoxic properties of Bis(2-ethylhexyl) phthalate.

Phytol, Oleic acid and cis-11-Hexadecenal are diterpene alcohol, monounsaturated fatty acid and fatty aldehydes respectively. They have RT of 14.246 and peak of $7.03 \%$. Phytol is the product of chlorophyll metabolism in plants. It is used in the manufacturing of Vitamin E and K1 which are important in the many functions of the human body. It is used along with simple or corn syrup as a hardener in candies (Inoue et al., 2005, Sathiyabalan et al., 2014). Phytol has been reported to show vast biological activities like anxiolytic, metabolism-modulating, cytotoxic, antioxidant, autophagy- and apoptosis-inducing, antinociceptive, antiinflammatory, immune-modulating, and antimicrobial effects (Islam et al., 2018). It has also been reported to have anti-cancer properties with effects on both Gastric Adenocarcinoma Cells (AGS) (Song and Cho, 2015), Glioblastomas (Gustavo et al., 2017) and antischistosomal properties (Josue' et al., 2014). Oleic Acid has 5- $\alpha$ reductase inhibitory, allergenic, anti-inflammatory, anti-androgenic, cancer preventive, anemiagenic, anti- 
alopecic, anti-leukotriene-D4, choleretic, dermatitigenic, hypocholesterolemic, insectifuge, perfumery, propecic and flavour activities (Pauldasan et al., 2020).

6,9,12-Octadecatrien-1-ol, and Ethanol, 2-(9,12-octadecadienyloxy)-, (Z, Z)- are fatty acid and alcoholic compound with RT of 14.946 and peak of $6.65 \%$ respectively. It has antioxidant, antibacterial (Elango et $a l ., 2015)$ and antimicrobial properties (Sana et al., 2019)

5-Eicosene, (E)-, 3-Eicosene, (E)-, and 1-Octadecene are fatty acids and alkene compounds respectively. They have RT of 10.372 and peak of $4.63 \%$. The fatty acids have antimicrobial, antihyperglycemic, cytotoxic activity, antioxidant, and insecticidal activities (Yogeswari et al., 2012; Banakar and Jayaraj, 2018). Indra et al., 2018 reported the antibacterial, and antioxidant properties of 1-Octadecene.

9,17-Octadecadienal, (Z)- and cis-7, cis-11 Hexadecadien-1-yl acetate are unsaturated aldehyde and acetate compounds. It has RT of 14.857 and peak of $4.24 \%$. 9,17-Octadecadienal, (Z)- has been reported to have antimicrobial (Karthika and Paulsamy 2014). n-Hexadecanoic acid, n-Decanoic acid, and L-Galactose, 6-deoxyare fatty acids and sugar compounds respectively. They have RT of 9.105 and peak area of $4.09 \%$. The nHexadecanoic acid has been reported to possess antioxidant, hypocholesterolemic, nematicide, pesticide, lubricant, antiandrogenic, flavour, hemolytic and 5- alpha, reductase inhibitor (Pauldasan et al., 2020). It has also been reported to be a potent mosquito larvicide (Abubakar and Majinda, 2016), anticancer, anti-pesticide, antimicrobial activities (Hameed et al., 2015). n-Decanoic, also known as capric acid been reported to possess antifungal (Sathya et al., (2016). It is used in the manufacture of esters for artificial fruit flavors and perfumes. It is also used as an intermediate in chemical syntheses. Capric acid is used in organic synthesis and industrially in the manufacture of perfumes, lubricants, greases, rubber, dyes, plastics, food additives and pharmaceuticals. Capric acid may be responsible for the mitochondrial proliferation associated with the ketogenic diet, which may occur via PPAR gamma receptor agonism and the targeting of genes involved in mitochondrial biogenesis (PMIDL 24383952). The L-Galactose, 6-deoxy- has been reportedly used as Flavouring agent (Azhagu,2021) Trans-13-Octadecenoic acid and 1-Eicosene are fatty acid and alkene compounds with RT of 15.261 and peak of $3.81 \%$. Trans-13-Octadecenoic acid has been reported to possess anti-inflammatory, antiandrogenic, dermatitigenic, anaemiagenic, insecticides, flavour properties (Awonyemia et al., 2020). Khurshid. et al., 2018 has also reported the antimicrobial property of and 1-Eicosene.

\section{CONCLUSIONS}


The GC-MS analysis of ethanol leaf extract of Sphenocentrum jollyanum has revealed the presence of various secondary metabolites with various degrees of biological activities. The presence of these various bioactive compounds confirms the application of Sphenocentrum jollyanum leaves for various ailments by traditional practitioners which includes antibacterial, antioxidant, antitumor and antifungal activities. However, further investigation is required for the possible isolation and development of novel drugs using some of the phytochemicals and bioactive compounds found in Sphenocentrum jollyanum.

\section{CONFLICT OF INTERESTS}

There is no conflict of interest between authors.

\section{ACKNOWLEDGEMENTS}

The authors are grateful to Mr. Isa Abdu Yakubu of Multi-User Science Research Laboratory, Ahmadu Bello University, Zaria, for his technical assistance during this work.

\section{CONFLICT OF INTERESTS}

We have no conflict of interests.

\section{REFERENCES}

1. Biren, N. Shah., and Seth, A.K.: Textbook of Pharmacognosy and phytochemistry.2 ${ }^{\text {nd }}$ Edition, CBS publishers and Distributors PVT Ltd, New Delhi, India (2017).

2. Ipsos, Mori.: Public perceptions of Herbal medicines general public qualitative and quantitative research. IPSOS-MORI, London, UK (2008).

3. Kuntal, Das. (2019). Medicinal plants: "Their importance in pharmaceutical sciences". Kalyany publishers, New Delhi, India (2019)

4. Yamamoto, Y., Gaynor, R.B.: Therapeutic potential of inhibition of the NF-kappaB pathway in the treatment of inflammation and cancer. J Clin Invest; 107 (2001) 135-42.

5. Fadeyi, S.A., Fadeyi, O.O., Adejumo, A.A., Okoro, C., Myles, E.L.: In vitro anti-cancer screening of 24 locally used Nigerian medicinal plants. BMC Complement Altern Med.; 13 (2013) 79 
6. Ncube, N.S., Afilayan, A.J., Okoh, A.I.: Assessment techniques of antimicrobial properties of natural compounds of plant origin: current methods and future trends. African Journal of Biotechnology;7 (2008)17971806.

7. Tripathie, J. N.: Role of Biotechnology in Medicinal Plants. Tropical Journal of Pharmaceutical Research 2 (2003) 243-253.

8. Nia, R, Paper, D. H., Essien, E. E., Iyanch, K.C., Bassey, A. I. L. Antai, A. B., Franz, G.: Evaluation of the anti-oxidant and anti-angiogenic effects of Sphenocentrum Jollyanum Pierre. Afr. J. Biomed. Res.; 7 (2004)129-132.

9. Amidu N. An Evaluation of the Central and Sexual Behavioral Effects and Toxicity of the Root Extract of Sphenocentrum jollyanum Pierre (Menispermaceae) [Ph.D. Thesis]. Department of Molecular Medicine, Kwame Nkrumah University of Science \& Technology, Kumasi, Ghana. 2008.

10. Woode, E., Anidu, N, Willam, K. B. A., Owiredu, E., Boakye-Gyasi, E. F. Laing, C. Assah and M. Duwiejua.: Anxiogenic-like effects of a root extract of Sphenocentrum Jollyanum Pierre in Murine Behavioural Models. Journal of Pharmacology and Toxicology 4 (2009) 91-102.

11. Owiredu, W. K.B.A., Amidu, N., Woode, E.: The Effects of Ethanolic extract of root of Sphenocentrum jollyanum pierre on Sexual Behavior and hormonal levels in rodents. Journal of Science and Technology 27(2007) 9-21.

12. Olorunnisola, O. S., Akintola, A. O., Afolayan, A. J.: Hepatoprotective and antioxidant effects of Sphenocentrum jollyanum (Menispermaceae)stem bark extract against CC14 induced oxidative stress in rats. African Journal of pharmacy and Pharmacology 5 (2011) 1241-1246.

13. Moody, J. O., Robert, V. A., Connoly, J. D. and Houghton, P. J.: Anti-inflammatory activities of the methanol extracts and an isolated furanoditerpene constituent of Sphenocenthrum Jollyanum (Menispermaceae). Journal of Ethnopharmacology 104 (2006) 87-91.

14. Mbaka, G. O., Adeyemi, O. O., Ogbonnia, S.O, Noronha, C. C., Okanlawon, O.A.: The protective effect of ethanol root extract of Sphenocentrum Jollyanum on the morphology of pancreatic beta cells of alloxan challenged rabbit. Journal of morphological science, 28 (2011) 37-45.

15. Iwu, M. M.: Handbook of African medicinal plants. CRC press INC. (1993) 239.

16. Egunyomi, A., Fashola, T. and Oladunjoye, O.: Charring Medicinal Plants: A Traditional Method of Preparing Phytomedicines in South-Western Nigeria. Ethno-botanical Journal; 3 (2005) 261 - 265.

17. Burkill, H. M.: The Useful Plants of West Tropical Africa; UK, Royal Botanical Gardens, 1 (1985)1-7. 
18. Uma, G., Balasubramaniam, V.: GC-MS analysis of Nothapodytes nimmoniana, Mabberly leaves. $J$ Chem Pharm 4(2012):4417-4419.

19. Héthelyi, E., Tétényi, P., Dabi, E., Dános, B.: The role of mass spectrometry in medicinal plant research. Biomed Environ Mass Spectrom 14(19897) 627-632

20. Uka, E., Oboso, E. E., Akaninyene, O. E., Imoh, E. J.: Phytochemicals, acute toxicity and in-vitro antioxidant activity of ethanol extract of Sphenocentrum jollyanum leaves. Journal of Drugs and Pharmaceutical Science; 4(2020a) 10-20.

21. Uka, Emmanuel, Jessie Idongesit Ndem, Patrick Amagwu Iberi, Esther Oluwasola Aluko.: In-vivo analgesic activity of ethanol leaf extract of Sphenocentrum Jollyanum in albino mice. International Journal of Research Publication 64 (2020b) http://ijrp.org/paper-detail/1527

22. Pauldasan, A., Arockiyaehil, I.T. and Anand, V. G.: Phytochemical screening and GC-MS studies of Cyperus compressus Rottb. Journal of Medicinal Plants Studies; 8(2020) 90-93

23. Islam, M. T., Ali, E. S., Uddin, S. J., Shaw, S., Islam, M. A., Ahmed, M. I., Atanasov, A. G.: Phytol: A review of biomedical activities. Food and Chemical Toxicology; 121 (2018) 82-94

24. Ahsan, T., Chen, J., Zhao, X., Irfan, M. and Wu, Y.: Extraction and identification of bioactive compounds (eicosane and dibutyl phthalate) produced by Streptomyces strain KX852460 for the biological control of Rhizoctonia solani AG-3 strain KX852461 to control target spot disease in tobacco leaf. $A M B$ Express; 7 (2017) 54.

25. Roy, R. N., Laskar, S., and Sen, S. K.: Dibutyl phthalate, the bioactive compound produced by Streptomyces albidoflavus 321.2. Microbiological Research, 161(2006) 121-126.

26. Yogeswari, S., Ramalakshmi, S., Neelavathy, R. and Muthumary, J.: Identification and Comparative Studies of Different Volatile Fractions from Monochaetia kansensis by GCMS. Global Journal of Pharmacology; 6(2012) 65-71

27. Banakar, P. and Jayaraj, M.: Gc-Ms Analysis of Bioactive Compounds from Ethanolic Leaf Extract of Waltheria Indica Linn. And Their Pharmacological Activities. International Journal of Pharmaceutical Science and Research; 9(2018) 2005-2010.

28. Amudha, P., Jayalakshmi, M., Pushpabharathi, N. and Vanitha, V.: Identification of Bioactive Components in Enhalus Acoroides Seagrass Extract by Gas Chromatography-Mass Spectrometry. Asian Journal of Pharmaceutical and Clinical Research; 11(2018) 313-317 
29. Kalaivani, R. Arulmozhi, P. and Bakiyalakshmi, S.V.: A Study on Medicinal Properties of Traditional Rice Karung Kavuni and Neutraceutical Formulation. International Journal of Food and Nutritional Science; 5(2018) 86- 90.

30. Bu, T., Liu, M., Zheng, L., Guo, Y., and Lin, X.: $\alpha$-glucosidase inhibition and the in vivo hypoglycemic effect of butyl-isobutyl-phthalate derived from the Laminaria japonica rhizoid. Phytotherapy Research, 24(2010) 1588-1591.

31. El-Sayed, O.H., Asker, M.M.S., Shash, S.M. and Hamed, S.R.: Isolation, Structure elucidation and Biological Activity of Di- (2-ethylhexyl) phthalate Produced by Penicillium janthinellum. International Journal of ChemTech Research; 8(2015) 58-66

32. Adeniyi, S. Adegoke., Oke, V. Jerry., and Olatunji, G. Ademola.: GC-MS Analysis of Phytochemical Constituents in Methanol Extract of Wood Bark from Durio Zibethinus Murr. International Journal of Medicinal Plants and Natural Products; 5(2019) 1-11

33. Adeyemi, M. A., Ekunseitan, D. A., Abiola, S. S., Dipeolu, M. A., Egbeyale, L. T., Sogunle, O. M.: Phytochemical Analysis and GC-MS Determination of Lagenaria breviflora R. Fruit. International Journal of Pharmacognosy and Phytochemical Research; 9(2017)1045-1050.

34. Juliet, O. Oni., Ferdinand, A. Akomaye., Aniedi-Abasi, A. Markson., and Augustine, C. Egwu.: GC-MS Analysis of Bioactive Compounds in Some Wild-Edible Mushrooms from Calabar, Southern Nigeria. European Journal of Biology and Biotechnology;1(2020)1-9

35. Godswill, N. Anyasor., Onajobi,F., Osilesi, O., Adebawo, O., Efere, M. Oboutor.: Chemical constituents in n-butanol fractions of Costus afer ker Gawl leaf and stem. Journal of Intercultural Ethnopharmacology; $3(2014) 78-84$

36. Vikrama, Chakravarthi. P., Murugesan, S., Arivuchelvan, A., Sukumar, K., Arulmozhi, A., and Jagadeeswaran, A.: GC-MS profiling of methanolic extract of Piper betle (Karpoori Variety) leaf. Journal of Pharmacognosy and Phytochemistry; 7(2018) 2449-2452

37. Yirankinyuki, F. Fai., Buhari, Magaji., Wilson, L. Danbature., and Abdullah, M. Abdullah.: Identification of Active Compounds of Annona muricata (Soursop) Leaf Wax Extract Using GC-MS. Archives of Current Research International 20(2020)17-21.

38. Indra, Rautela., Manish, Dev. Sharma., Nishesh, Sharma., Kunal, Kishor., Keerti, Singh., Narotam, Sharma.: World Journal of Pharmaceutical Research; 7(2018) 956-972. 
39. Sathya, S., Lakshmi, S., and S. Nakkeeran, S.: Combined effect of biopriming and polymer coating on chemical constituents of root exudation in chilli (Capsicum annuum L.) cv. K 2 seedlings. Journal of Applied and Natural Science; 8 (2016) 2141-2154.

40. Sahil, K., Prashant, B., Akanksha, M., Premjeet, S., Devashish, R.: GC-MS: Applications. International Journal Pharma \& Biological Archives 2(2011)1544-1560.

41. Jenke, D.R.: Chromatographic Method Validation: A review of Current Practices and Procedures. I. General Concepts and Guidelines. J. Liq Chrom \& Rel Technol 19 (1996)737-757.

42. Susha, Cheriyedath.: Gas Chromatography-Mass Spectrometry (GC-MS) Applications. www.newsmedical.net/life-sciences/Gas Chromatography-Mass Spectrometry (GC-MS)-Applications. aspx. (2019).

43. Ndiege, Lilian. Merab., Fredrick, Kengara., and Geoffrey, Kattam. Maiyoh.: Characterization of Phenolic Compounds from Leaf Extract of Bidens Pilosa Linn. Var. Radiata. South Asian Research Journal of Natural Products 4(2021): 44-58.

44. Mohamed, A. Abdel-Wahab., Ali, H. A. Bahkali., Abdallah, M. El-Gorban., and Mohamed, S. Hodhod.: Natural products of Nothophoma multilocularis sp. nov. an endophyte of the medicinal plant Rhazya stricta. Mycosphere 8(2017): 1185-1200.

45. Azhagu, Madhavan., S.: Pharmacological constituents and GC-MS analysis of bioactive compounds present in methanol leaf extract Moringa oleifera. International Journal of Pharmaceutical Sciences and Drug Analysis; 1(2021) 51-57

46. Karthika, Krishnamoorthy., Paulsamy, Subramaniam.: Phytochemical Profiling of Leaf, Stem, and Tuber Parts of Solena amplexicaulis (Lam.) Gandhi Using GC- MS. Hindawi Publishing Corporation International Scholarly Research Notices. (2014)1- 13

47. Sana, Khan., Richa., Harsimran, Kaur., and Rinku, Jhamta.: Evaluation of antioxidant potential and phytochemical characterization using GCMS analysis of bioactive compounds of Achillea filipendulina (L.) Leaves. Journal of Pharmacognosy and Phytochemistry; 8(2019) 258-265.

48. Hameed, Hadi. Imad., Huda, Jasim. Altameme., and Ghaidaa, Jihadi. Mohammed.: Evaluation of Antifungal and Antibacterial Activity and Analysis of Bioactive Phytochemical Compounds of Cinnamomum zeylanicum (Cinnamon bark) using Gas Chromatography-Mass Spectrometry. Orient. Journal of Chemistry., 32(2016) 1769-1788. 
49. Awonyemia, Isaac. Olatunde., Michael, Segun. Abegundeb., and Temitope, Esther. Olabirana.: Analysis of bioactive compounds from Raphia taedigera using gas chromatography-mass spectrometry. Eurasian Chemical Communications. 2(2020) 938-944.

50. Adeyemi, M. A., Ekunseitan, D. A., Abiola, S. S., Dipeolu, M.A., Egbeyale, L. T., Sogunle, O. M.: Phytochemical Analysis and GC-MS Determination of Lagenaria breviflora R. Fruit. International Journal of Pharmacognosy and Phytochemical Research; 9(2017)1045-1050 51. Khurshid, S., Javaid, A., Shoaib, A., Javed, S., and Qaisar, U.: Antifungal activity of aerial parts of Cenchrus pennisetiformis against Fusarium oxysporum f. sp. Lycopersici. Planta Daninha; 36(2018) e018166627.

52. Mary, F. P. A., and Giri, S.R.: GC-MS Analysis of bioactive compounds of Achyranthes Aspera. World Journal of Pharmaceutical Research;7(2018) 1045-1056.

53. Thenmozhi, S., and Rajan, S.: GC-MS analysis of bioactive compounds in Psidium guajava leaves. Journal of Pharmacognosy and Phytochemistry; 3(2015)162-166.

54. Inoue, Y., Hada, T., Akiko, Shiraishi., Kazuma, Hirore., Hajime, Hamashima., and Shigeki, Kobayashi.: Biphasic effects of Geranylgeraniol, Terpenone and Phytol on the growth of Staphylococcus aureus. Antimicrobial Agents Chemotherapy. 49(2005) 1770-1774.

55. Sathiyabalan, G., Packia, L.M., Muthukumarasamy, S., and Mohan, V.R.: GC-MS analysis of bioactive components of Petiveria alliacea L. whole plant (Phytolaccaceae). International Journal of Pharma Research Health Science. 2(2014) 387-392.

56. Neeraj, Neeru, Vasudeva., and Sunil, Sharma.: Chemical Composition of Fagopyrum Esceulentum Seed through GC-MS. International Journal of Pharmaceutical Sciences and Research; 10(2019)2392-2396.

57. Govindaraj, Sabithira., and Rajangam, Udayakumar.: GC-MS Analysis of Methanolic Extracts of Leaf and Stem of Marsilea minuta (Linn.) Journal of Complementary and Alternative Medical Research; 3(2017)113. 